
\title{
Journal of Management
}

\section{Assessing Managerial Power Theory: A Meta-Analytic Approach to Understanding the Determinants of CEO Compensation \\ Marc van Essen, Jordan Otten and Edward J. Carberry \\ Journal of Management published online 5 January 2012 \\ DOI: $10.1177 / 0149206311429378$}

The online version of this article can be found at:

http://jom.sagepub.com/content/early/2012/03/06/0149206311429378

\author{
Published by: \\ (\$) SAGE \\ http://www.sagepublications.com

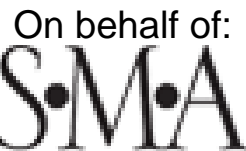 \\ SOUTHERN \\ MANAGEMENT \\ Southern Management Association
}

Additional services and information for Journal of Management can be found at:

Email Alerts: http://jom.sagepub.com/cgi/alerts

Subscriptions: http://jom.sagepub.com/subscriptions

Reprints: http://www.sagepub.com/journalsReprints.nav

Permissions: http://www.sagepub.com/journalsPermissions.nav

>> OnlineFirst Version of Record - Mar 13, 2012

OnlineFirst Version of Record - Jan 5, 2012

What is This? 
Journal of Management

Vol. XX No. X, Month XXXX xx-xx

DOI: $10.1177 / 0149206311429378$

(C) The Author(s) 2012

Reprints and permission: http://www.

sagepub.com/journalsPermissions.nav

\title{
Assessing Managerial Power Theory: A Meta-Analytic Approach to Understanding the Determinants of CEO Compensation
}

\author{
Marc van Essen \\ Utrecht University \\ Jordan Otten \\ Edward J. Carberry \\ Erasmus University
}

\begin{abstract}
Although studies about the determinants of CEO compensation are ubiquitous, the balance of evidence for one of the more controversial theoretical approaches, managerial power theory, remains inconclusive. The authors provide a meta-analysis of 219 U.S.-based studies, focusing on the relationships between indicators of managerial power and levels of CEO compensation and CEO pay-performance sensitivities. The results indicate that managerial power theory is well equipped for predicting core compensation variables such as total cash and total compensation but less so for predicting the sensitivity of pay to performance. In most situations where CEOs are expected to have power over the pay setting process, they receive significantly higher levels of total cash and total compensation. In contrast, where boards are expected to have more power, CEOs receive lower total cash and total compensation. In addition, powerful directors also appear to be able to establish tighter links between CEO compensation and firm performance and can accomplish this even in the face of powerful CEOs. The authors discuss the implications for theory and research regarding the determinants of executive compensation.
\end{abstract}

Keywords: executive compensation; managerial power theory; agency theory; corporate governance; meta-analysis

\footnotetext{
Acknowledgments: We would like to thank the editor Yasemin Kor, two anonymous reviewers, Tammo Bijmolt, Chris Doucouliagos, Peter Jan Engelen, Inge Geyskens, Pursey Heugens, Michel Lander, Hans van Oosterhout, Taco Reus, Pushpika Vishwanathan, and David Wilson for their helpful comments and suggestions and Anna Doubrovskaia for her research assistance.
}

Corresponding author: Jordan Otten, Rotterdam School of Management, Erasmus University, Room T7-17, Burgemeester Oudlaan 50, 3062 PA Rotterdam, Netherlands

E-mail: jotten@rsm.nl 
Although research on CEO compensation continues to proliferate (Barkema \& Gomez-Mejia, 1998; Devers, Cannella, Reilly, \& Yoder, 2007; Finkelstein \& Hambrick, 1988, 1989; Gomez-Mejia \& Wiseman, 1997; Murphy, 1999; Tosi, Werner, Katz, \& GomezMejia, 2000), there remains a lack of interdisciplinary consensus regarding the primary forces shaping observable patterns of executive compensation. The lack of consensus is most visible between scholars in economics and finance who advocate for the primacy of marketbased explanations (e.g., Jensen \& Meckling, 1976; Murphy, 2002; Murphy \& Zábojník, 2004) and scholars outside of these two disciplines who have challenged these explanations and some of their underlying assumptions by highlighting the importance of power (Bebchuk \& Fried, 2004), social-psychological processes (O’Reilly \& Main, 2010), and the institutional environment (Diprete, Eirich, \& Pittinsky, 2010) in the creation of compensation practices. This division has generated much productive discussion, although it is but the latest manifestation of long-running debates between neoclassical and managerialist traditions examining executive compensation (Finkelstein, Hambrick, \& Cannella, 2009).

The most prominent recent challenger to purely market-based explanations is managerial power theory (MPT) advanced by Bebchuk and Fried (Bebchuk \& Fried, 2004; Bebchuk, Fried, \& Walker, 2002). At the core of this framework is a direct challenge to the common assumption within agency theory of optimal contracting, that is, that boards engage in arm's-length transactions with executives over compensation arrangements and that such transactions help mitigate agency problems by creating compensation practices that more closely align the interests of executives and shareholders. In contrast, Bebchuk and Fried (2004) argue that boards rarely engage in arm's-length transactions because CEOs often have power over board members because of specific structural and social-psychological mechanisms that have an important influence over board-level decision-making processes about executive compensation. These mechanisms create few incentives for directors to challenge compensation arrangements that are more in the interest of executives than shareholders, that is, higher levels of compensation and compensation that is less sensitive to performance. The goal of MPT, however, is not to refute agency theory but to deepen it by arguing that managerial power and its influence on executive compensation cast doubt on the assumption of optimal contracting. According to MPT, managerial power over pay-setting processes results in executive compensation practices that often function not as solutions to agency problems within large publicly listed firms, as agency theorists have argued, but that are in fact manifestations of these problems.

Some scholars in finance and economics have, in turn, critiqued MPT, drawing on various types of evidence. First, these critiques have pointed to the simultaneous increase in CEO pay and independence of boards of directors during the 1990s as inconsistent with MPT. If boards were becoming more independent, these critics argue, MPT would predict that CEOs would have actually been less able to influence the pay-setting process and thus less able to realize increasing levels of pay (Conyon, 2006; Hall \& Murphy, 2003; Murphy, 2002; Murphy \& Zábojník, 2004). Second, critics of MPT have argued that the increase in both the hiring rate and pay levels of externally hired CEOs relative to internal candidates goes against MPT's claim that incumbent CEOs have more power than externally hired CEOs (Hall \& Murphy, 2003; Murphy, 2002; Murphy \& Zábojník, 2004). Third, challengers to MPT have argued that the low incidence of indexed stock options can be attributed more to 
their accounting treatment (at least before 2004) than to managers being able to use their power to negotiate for less risky and more accounting-friendly "plain vanilla" stock options (Conyon, 2006). Fourth and finally, recent critiques of MPT have pointed to other trends in executive compensation, such as aggregate-level associations between corporate performance and compensation as well as the shortening of CEO tenures over time, as evidence against MPT (Kaplan, 2008). Critics of MPT have used this evidence to claim that MPT is not supported by the empirical evidence (Murphy, 2002).

In assessing these critiques, it is clear that they raise important questions about the extent and influence of managerial power. However, they do not provide sufficient evidence to make definitive claims about the validity of MPT. Although Bebchuk and Fried (2004) have raised counterarguments to some of these critiques directly, a more fundamental point is that most of these challenges have not been based on direct tests of the relationship between indicators of managerial power and compensation outcomes at the firm level (although for important exceptions, see Conyon, 2006; Conyon \& He, 2004). Instead, these critiques have tended to focus on aggregate-level trends relating to board independence, compensation, firm performance, and CEO turnover. We contend, however, that the two core questions for testing the validity of MPT should be the following: (a) Do CEOs who have more power over their boards have higher compensation levels than CEOs with less power? and (b) Do CEOs who have more power over directors have compensation that is less sensitive to firm performance than that of CEOs with less power? Analyzing aggregate-level trends is suggestive but does not provide sufficient evidence to rigorously evaluate these two questions.

Fortunately, a large and diverse number of studies have examined these relationships empirically at the firm level. The literature, however, remains inconclusive and is characterized by divergent and conflicting findings that have allowed both proponents and opponents of MPT to put forward evidence to support different claims (O'Reilly \& Main, 2010). For example, several studies find that CEO duality, a manifestation of CEO power, is related to higher pay (e.g., Yermack, 1996), whereas other studies find no such relationship between CEO duality and pay at all (e.g., Boyd, 1994). Therefore, what is needed at this stage is a more rigorous assessment of the existing literature, one that consolidates the mixed empirical findings and assesses the general explanatory validity of MPT regarding levels of compensation and the sensitivity of compensation to firm performance.

In this article, we offer both a consolidation and an assessment of this literature with the help of meta-analytic methods. Meta-analyses have become increasingly common in management research (Carney, Gedajlovic, Heugens, van Essen, \& van Oosterhout, 2011; Dalton, Daily, Ellstrand, \& Johnson, 1998; Deutsch, 2005; Heugens \& Lander, 2009; Tosi et al., 2000) as a useful and robust way to analyze relationships between variables that have been examined in a large number of studies. Despite scores of empirical studies examining managerial power, the evidence and results remain subject to much ambiguity and controversy. In situations where there are large numbers of studies with mixed and conflicting findings, meta-analytic techniques can play an important role in providing a comprehensive and rigorous assessment of the balance of evidence with data that are closer to definitive than those reported in any single primary study (C. C. Miller \& Cardinal, 1994). 
We use these techniques to assess the accumulated evidence of 219 studies that measure the influence of managerial power directly on both CEO compensation levels and the relationship between corporate performance and CEO pay. Since the vast majority of studies have focused on the United States, we limit our sample to this context. Although testing managerial power was not necessarily the primary focus of every study in our data set, all of them have examined relationships between specific variables that allow us to test MPT using meta-analytical techniques. In addition to providing a meta-analytic assessment of MPT, we update Tosi et al. (2000), the first meta-analysis of the executive compensation literature, which provided a key assessment of the effects of firm size and performance on CEO pay. Their study, however, focused on these two determinants of executive pay separately and did not examine the influence of corporate governance variables, such as board and firm ownership structures, that are indicators of the power of different actors over the pay-setting process. We specifically investigate the possible moderating effects of these variables on performance-pay relationships, which Tosi et al. (2000) indicated as missing components of their analysis. Furthermore, Tosi et al.'s (2000) study was conducted over a decade ago and included 42 studies. Our analysis includes 219.

In addition, this article extends the application of meta-analytical methodology for management and organizational research in three ways (Combs, Ketchen, Crook, \& Roth, 2011). First, our study is among the first in management research to use partial correlations as effect sizes (Carney et al., 2011). Using partial correlations allows us to incorporate studies from disciplinary domains such as finance and economics in which bivariate effect size information is not commonly reported and to control for the direction of causality between firm performance and CEO compensation (Sánchez-Ballesta \& García-Meca, 2007). Moreover, we run bivariate and partial Hedges and Olkin-type meta-analyses (HOMA; Hedges \& Olkin, 1985) to assess the balance of evidence regarding the antecedent variables and different CEO pay components. A second extension is that we employ metaanalytic regression analyses (MARA; Lipsey \& Wilson, 2001) to model the moderating effects of a broad range of managerial power and control variables on the focal relationship between performance and pay (Doucouliagos \& Ulubaşoğlu, 2008). Finally, we make use of meta-analytic structural equation modeling (MASEM; Cheung \& Chan, 2005) to test the direct effect of all indicators of power on the level of CEO compensation.

Ultimately, the primary goal of this article is to help advance the debate about MPT by using the methodological power of meta-analytical techniques to assess the accumulated evidence to date. Our goal is not to argue that finance and economics scholars have been wrong in their critiques of MPT but that their evidence does not go far enough in its assessment of MPT. We believe that testing MPT requires more rigorous analysis and that meta-analytic techniques provide a powerful set of tools that have yet to be used to assess MPT. Ultimately, such an assessment will help us assess whether and how MPT expands agency theory explanations of the antecedents of executive compensation.

\section{Manifestations of Managerial Power}

Bebchuk and Fried (2004) argue that when CEOs have more power over the board of directors, they will be better positioned to negotiate for compensation arrangements that 
serve their own interests, that is, they will be better able to negotiate for higher pay and pay that is less sensitive to their firm's performance. This fundamental claim of MPT rests on a challenge to the common optimal contracting assumption within agency theory, which posits that managers and boards negotiate in arm's-length transactions over compensation, with directors acting as selfless agents of shareholders and negotiating for compensation arrangements that serve the interests of shareholders rather than executives. However, if we assume self-interested behavior by executives, it is also logical to assume possible selfinterested behavior by directors, such that delegating decision-making responsibilities to boards of directors may also lead to agency problems between shareholders and the board.

Bebchuk and Fried (2004) highlight a number of reasons why directors might not have the incentives to negotiate in the interests of shareholders and, in fact, may have incentives to go along with compensation arrangements that favor executives. First, since directors' positions confer status, connections, and compensation, most directors will want to keep their positions and be reelected, and CEOs will exert a powerful influence over director selection (also see Main, O’Reilly, \& Wade, 1995). Second, social and psychological mechanisms that have been found to be common within small groups, such as friendship, loyalty, and collegiality, are also common to boards and make directors less likely to challenge CEOs (O'Reilly \& Main, 2010). Third, CEOs are in positions to reward directors directly through higher compensation, new business, and charitable contributions. These incentives make it likely that executives who wield power over board members will be better positioned to negotiate for compensation arrangements that are in their favor.

The recognition of such incentives challenges the assumption of arm's-length transactions that represent the core insights of MPT. However, as Bebchuk and Fried (2004) and others (Finkelstein et al., 2009) have pointed out, MPT is in line with a long history of work stretching back to Berle and Means (1932) that has attended to the role of social and political forces in shaping executive compensation. Like earlier work, MPT has proven to be provocative and has generated a number of critics (e.g., Conyon, 2006; Kaplan, 2008; Murphy, 2002; Murphy \& Zábojník, 2004). Although most of these critiques, as noted above, have not tested MPT directly by examining the firm-level relationships between managerial power compensation and performance, MPT provides a simple prediction that is empirically testable: If executives have more power over the board, they will have more power to influence the design of their compensation arrangements. Since executives prefer more compensation and less risky arrangements (Baker, Jensen, \& Murphy, 1988), when they have power over the board we would expect executives to receive higher pay and pay that is less sensitive to performance (Bebchuk \& Fried, 2004). In addition, since social psychologists and sociologists have long viewed power as a relationship (Blau, 1964; Emerson, 1962; Pfeffer \& Salancik, 1978), MPT also leads to the opposite prediction: When boards have more power over CEOs, CEOs will have lower compensation and pay that is more sensitive to corporate performance.

Hence, the core prediction of MPT can be tested directly in two ways: by examining the power that a CEO has over the board and by examining the power that boards have over CEOs. If our analysis finds higher levels of pay and pay that is less sensitive to performance when executives have more power, and the opposite when directors have more power, this will provide empirical evidence in favor of MPT. To test these predictions, scholars have 
relied on a number of different indicators of CEO and board power (Finkelstein et al., 2009), each of which has been linked to specific theoretical mechanisms. In this section, we hypothesize the primary ways in which managerial and board power manifests itself and can influence the level of executive compensation and its relationship with firm performance. We focus on the two sets of mechanisms on which researchers have focused most frequently when analyzing managerial power: board structures (Dalton et al., 1998; van Essen, van Oosterhout, \& Carney, in press) and ownership characteristics (Dalton, Daily, Certo, \& Roengpitya, 2003; Hambrick \& Finkelstein, 1995). We hypothesize that the effect that each mechanism will have on the ability of managers to receive both higher pay levels and pay that is less sensitive to firm performance.

\section{Board Characteristics}

Structural features of boards of directors can constrain or enable managerial power in the pay-setting process. The common agency theory assumption of optimal contracting sees boards as representatives of shareholders and therefore able and willing to monitor and constrain managerial power (e.g., Conyon \& Peck, 1998; Finkelstein, 1992; Yermack, 1996). Managerial power theorists, however, have challenged this assumption that boards of directors engage in arm's-length transactions in which they will act as selfless agents of shareholders (Bebchuk \& Fried, 2004). A more nuanced view would be that under certain conditions boards will be more or less influenced by executives and hence more or less able to constrain executive power in the compensation-setting process. We focus on four firmlevel characteristics that allow us to predict when directors will be more or less influenced by CEOs and consequently be less or more able to constrain managerial power: CEO duality, CEO tenure, size of the board, and the percentage of independent directors.

A key structural governance feature is CEO duality, in which an individual has the roles of both CEO and board chairman. MPT predicts that the concentration of decision-making power in one individual leads to more power, for several possible reasons (Finkelstein \& D'Aveni, 1994). First, since the CEO-chairman is responsible for organizing board meetings and setting the agendas of these meetings, the CEO-chairman is able to control the information provided to the board of directors (Bebchuk \& Fried, 2004; Pearce \& Zahra, 1991). Second, CEO duality increases the CEO's influence over the nomination process of new directors (Westphal \& Zajac, 1995). Third, the dual role of CEO and chairman can be considered as the highest rank in the corporate hierarchy. This figurehead status, with more mandate and power, can lead to more influence over the pay setting process (Ungson \& Steers, 1984). We therefore hypothesize,

Hypothesis 1a: CEO duality is positively associated with the value of total CEO compensation. Hypothesis $1 \mathrm{~b}$ : In the presence of CEO duality, the association between corporate performance and CEO compensation will be weaker.

The length of a CEO's tenure is also likely to be an important determinant of managerial power. Longer tenured CEOs can be expected to have more influence over board members and their decisions because they have more status and more experience with the company 
and its board (Bebchuk \& Fried, 2003, 2006). The collaboration among board members and bonds of collegiality intensify over time, and CEOs with longer tenure have more time to influence this process (Bebchuk \& Fried, 2004; Macey, 2008). CEOs with longer tenure can also be more influential over the remuneration committee directly. Evidence pointing in this direction shows that remuneration committees whose chairs have been installed later than the CEO tend to pay more (Main et al., 1995). Furthermore, other research has found that the relationship between firm performance and CEO pay weakens as tenure increases (Hill \& Phan, 1991). CEOs with longer tenure are therefore expected to have more power, and therefore we hypothesize,

Hypothesis 2a: CEO tenure is positively associated with the value of total CEO compensation.

Hypothesis 2b: In the presence of CEOs with longer tenure, the association between corporate performance and CEO compensation will be weaker.

The size of the board in terms of the number of directors is also likely to enable or constrain managerial power. Although monitoring requires capacity, large boards can be ineffective at constraining managerial power because larger boards require more time and effort to build consensus and generate the social cohesion of smaller boards (Zahra \& Pearce, 1989). In addition, larger boards can become ineffective because of internal coordination and communication problems (Bebchuk \& Fried, 2004). Therefore, the in-group monitoring and collective action problems of larger boards may provide executives with more power over the pay-setting process (Eisenberg, Sundgren, \& Wells, 1998; O’Reilly \& Main, 2010; Pfeffer, 1972; Yermack, 1996). We therefore hypothesize,

Hypothesis 3a: Board size is positively associated with the value of total CEO compensation.

Hypothesis $3 b$ : In the presence of larger boards, the association between corporate performance and CEO compensation will be weaker.

Finally, the composition of the board in terms of the percentage of independent directors may also influence managerial power. Directors are considered independent if they are not currently or have never been employees of the company and have no other relationship with the firm, such as business contracts (Bebchuk \& Fried, 2004). Agency theorists have argued that boards should be composed of independent directors (Zahra \& Pearce, 1989) who are less sensitive to the influence of corporate insiders and free of conflicts of interest (Dalton et al., 1998). In turn, this provides them with an incentive to protect their own reputations as expert independent decision makers and focus on improving corporate performance (Fama \& Jensen, 1983). However, MPT has highlighted a number of ways that independent directors can actually lose independence and become vulnerable to managerial influence, such as the role of CEOs in director selection, the close connections and bonds of shared interests and collegiality among board members, and the dependence of independent directors on managers for information (Bebchuk \& Fried, 2004). Moreover, the collaboration among independent board members and managers may intensify over time (Bebchuk \& Fried, 2004; Macey, 2008). In such situations, independent directors can become less willing to challenge executive compensation arrangements. Nevertheless, we expect independent directors in general to be better able to constrain executive power as opposed to directors 
who have been executives of the firms themselves or have some other relationship with the firm. We therefore hypothesize,

Hypothesis 4a: The percentage of independent directors is negatively associated with the value of total CEO compensation.

Hypothesis 4b: At higher levels of board independence, the relationship between corporate performance and CEO compensation will be stronger.

\section{Ownership Characteristics}

Both MPT and agency theory argue that the ownership structure of the corporation can enable or constrain the power of CEOs (Tosi et al., 2000). For example, large, concentrated owners often have both the means and incentives to monitor management effectively (Bebchuk \& Fried, 2004; Shleifer \& Vishny, 1986, 1997). More specifically, since these owners have large investment stakes, they are more dependent on the performance of the firm. In addition, large owners are more able to protect their interests by means of both formal influence, such as the nomination of and voting for directors, and informal communication with management (Smith, 1996). In contrast, for dispersed shareholders, who own only a small percentage of a firm, the costs of close monitoring may be too high relative to the possible gains produced by such monitoring. Instead of trying to steer managerial decisions directly, these shareholders are more inclined to "vote with their feet" and sell their shares if they disagree with executives or when the firm's performance falls below expectations (Heugens, van Essen, \& van Oosterhout, 2009; Hirschman, 1970). Moreover, dispersed shareholders are likely to have dispersed strategies and goals for increasing firm value, leaving management with more influence to make their own calls (Thomsen \& Pedersen, 2000). Earlier studies have also shown that the level of executive compensation is negatively associated with block holders who have holdings of $5 \%$ or more (e.g., Core, Holthausen, \& Larcker, 1999; Khan, Dharwadkar, \& Brandes, 2005; Lambert, Larcker, \& Weigelt, 1993; Mehran, 1995). The association between performance and pay (i.e., performance-pay sensitivity) is also more likely to be stronger at higher levels of concentrated ownership as these owners are expected to monitor management more closely and ensure executives make value-enhancing decisions (Bebchuk \& Fried, 2004; Shleifer \& Vishny, 1986, 1997). We therefore expect that corporations with more concentrated ownership structures will be better able to constrain managerial power and hypothesize,

Hypothesis 5a: Higher levels of concentrated ownership is negatively associated with the value of total CEO compensation.

Hypothesis 5b: At higher levels of concentrated ownership, the association between corporate performance and CEO compensation will be stronger.

In addition to the concentration of ownership, the identity of a firm's owners can also constrain or enable managerial power over executive compensation practices. For example, one of the most important governance changes in the past 20 years has been the dramatic increase in the holdings and number of institutional investors (Useem, 1996). Although their status as institutional investors does not give them more formal power than other investors, 
they often have substantial holdings and fiduciary obligations to their investors to improve the returns to their clients. Therefore, institutional investors tend to more actively monitor management than individual investors and may be more able to constrain executive power in setting compensation (Bebchuk \& Fried, 2004; David, Kochhar, \& Levitas, 1998; Hartzell $\&$ Starks, 2003). We therefore predict that institutional investors will act more often as a constraint on, instead of an enabler of, managerial power and hypothesize,

Hypothesis 6a: Higher levels of institutional ownership is negatively associated with the value of total CEO compensation.

Hypothesis 6b: At higher levels of institutional ownership, the association between corporate performance and CEO compensation will be stronger.

\section{Method and Data}

\section{Sample and Coding}

To identify the population of studies on CEO compensation in the U.S. context, we used five complementary search strategies (Heugens et al., 2009). First, we consulted several review articles (Barkema \& Gomez-Mejia, 1998; Devers et al., 2007; Gomez-Mejia \& Wiseman, 1997; Murphy, 1999) and two published meta-analyses (Deutsch, 2005; Tosi et al., 2000). Second, we located additional articles using five electronic databases, (a) ABI/INFORM Global, (b) EconLit, (c) Google Scholar, (d) JSTOR, and (e) SSRN, and the following search terms: bonus, compensation, incentive, long-term incentive plan (LTIP), pay, remuneration, salary, and stock option. Third, we conducted a manual search of 25 journals in the fields of accounting, economics, finance, and management. Fourth, after collecting an initial set of studies, we traced backward all references reported in the articles and traced forward all articles that cited the original articles using Google Scholar. Fifth, we corresponded with 82 researchers who had previously written one or several articles on the focal relationship in which effect size information was not reported or whose studies we could not retrieve, asking them for a correlation table and regression output. This strategy yielded a final sample of 219 primary studies, which consisted of 169 journal articles, 47 working papers, and 3 doctoral dissertations (see Appendix A).

In terms of samples used in the studies that we analyzed (see Table 1), about one third $(32.42 \%)$ relied on an index from Standard and Poor's (S\&P). In our sample, $8.22 \%$ of the studies used the S\&P 500, 10.96\% used the S\&P 1500, and 13.24\% of the studies indicated that they used the S\&P but did not specify which particular index. Another one quarter of the studies (26.94\%) analyzed samples based on lists published in Forbes, Fortune, or Business Week. The Fortune 500 comprises the 500 largest firms traded on U.S. stock exchanges in terms of revenues, and although Forbes and Business Week have published different lists over the past 20 years, they primarily include the largest publicly traded companies. Another one quarter $(26.48 \%)$ of the studies did not specify their samples, whereas the remainder used a mix of samples $(7.31 \%)$ or some other sample $(6.85 \%)$. Hence, despite the accessibility of the ExecuComp database, which is based on the S\&P 1500, only a little more than one third of the studies used it as their only sample. Nevertheless, a majority of the studies have been based on large, publicly traded companies. 
Table 1

Data Sources, Industries, and Sample Periods of Primary Studies

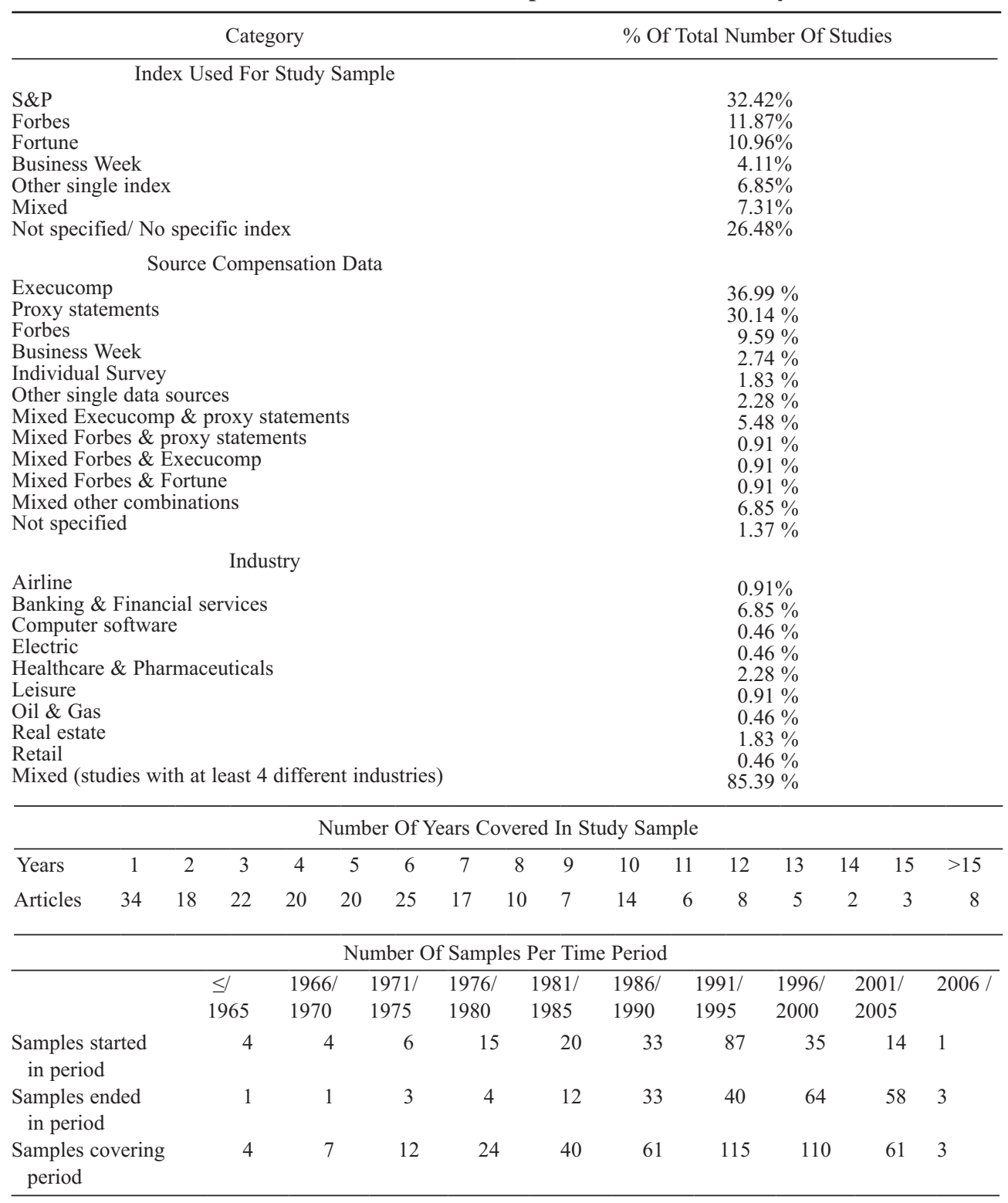


Table 1 also reports the frequency of the data sources used in the primary studies. More than one third of our sample (36.99\%) collected data from ExecuComp, which itself collects data from publicly available proxy statements. Another $30 \%$ of the studies in our sample used proxy statements, and about $13 \%$ of our sample used data published by Forbes or Business Week. Since these periodicals also draw on proxy statements, the vast majority of the studies in our sample relied on publicly available information about executive compensation available through proxy statements. Few researchers surveyed companies directly $(1.83 \%)$. In terms of industries sampled, $85 \%$ of the studies in our sample analyze four or more industries. Finally, as can be seen in Table 1, the primary studies included in our analyses covered different, but sometimes overlapping, time periods, with most studies beginning between 1991 and 1995 and ending between 1996 and 2000.

After reading the articles, we developed a coding protocol (Lipsey \& Wilson, 2001) for extracting data on relevant variables. Table 2 provides a description of the variables collected from the primary studies that are included in our meta-analyses. The coding protocol allowed us to differentiate between two types of firm financial performance, accounting performance and market performance, and among the most frequently used measures of CEO compensation, including salary, cash bonus, total cash (i.e., the sum of salary and cash bonus), LTIPs, and total compensation. LTIPs include long-term equity-based compensation (stock options, restricted stock units, and other long-term compensation) earned by the CEO during the year (e.g., Balkin, Markman, \& Gomez-Mejia, 2000).

For testing Hypotheses 1a, 2a, 3a, 4a, 5a, and 6a, we collected effect size information for all the variables predicted to influence CEO total compensation and the interrelationships among all dependent, independent, and control variables used in our analyses. More specifically, we collected Pearson product-moment correlations coefficients $(r)$ and sample sizes among all the variables. To test Hypotheses $1 \mathrm{~b}, 2 \mathrm{~b}, 3 \mathrm{~b}, 4 \mathrm{~b}, 5 \mathrm{~b}$, and $6 \mathrm{~b}$, we used partial correlation coefficients $\left(r_{x y . z}\right)$ between firm performance and CEO total compensation. We computed these from the multivariate $t$ statistics and degrees of freedom of the sampled regression analyses. To test our hypotheses, we also collected information about the study characteristics, methodological artifacts, and whether a particular variable was included in a study's regression model. This allowed us to test the impact of these characteristics on the strength of the performance to pay relationship (Bahadir, Bharadwaj, \& Parzan, in press; Doucouliagos \& Ulubaşoğlu, 2008).

One author coded all effect sizes. To assess agreement in extracting information from primary studies, another author independently coded a subsample of 512 randomly selected effect sizes. We then computed the percentage agreement and a chance agreement-corrected measure of reliability (Cohen's kappa coefficient; Cohen, 1960). The percentage agreement and kappa value we obtained were .93 and .90 , respectively, signifying a very high degree of reliability.

\section{MASEM Procedure}

We used MASEM (Cheung \& Chan, 2005) to test Hypotheses 1a, 2a, 3a, 4a, 5a, and 6a. The MASEM procedure combines the techniques of structural equation modeling with those of meta-analysis (Cheung \& Chan, 2005). The technique is ideally suited to test these 
Table 2

\section{Description of Variables}

\begin{tabular}{l} 
Variable \\
\hline CEO salary \\
CEO cash bonus \\
CEO total cash \\
CEO long-term incentive \\
plan (LTIP)
\end{tabular}

CEO total pay

Firm performance

Accounting performance

Market performance

CEO duality

CEO tenure

Board size

Board independence

Ownership concentration

Institutional ownership

Firm size

Firm debt

Firm diversification

Firm risk
Description

Measures the annual base salary earned by the CEO during the year (e.g., Khan, Dharwadkar, \& Brandes, 2005)

Measures the annual cash bonus earned by the CEO during the year (e.g., Gray \& Cannella, 1997)

Measures the annual total cash earned by the CEO during the year, defined as the sum of salary and cash bonus (e.g., Nourayi \& Mintz, 2008)

Measures long-term equity-based compensation (stock options, restricted stock, and other long-term compensation) earned by the CEO during the year (e.g., Balkin, Markman, \& Gomez-Mejia, 2000)

Measures the total annual compensation of the CEO; CEO total pay is the sum of total salary, cash bonus, and long-term compensation (grants of restricted stock, stock options, stock appreciation rights, and performance plans) in a year (e.g., David, Kochhar, \& Levitas, 1998)

Any indicator of the financial performance of the firm, including both accountingbased measures and market-based measures of firm value

Any indicator of the financial performance of the firm that is expressed in the form of an accounting-based measure of firm profits (return on assets, return on equity, earnings per share, and profit margin [PM])

Any indicator of the financial performance of the firm that is expressed in the form of a market-based measure of firm value (stock returns, market to book [MB], Tobin's $Q$ )

Measures whether the CEO is also the chairman of the board of directors (e.g., Grossman \& Cannella, 2006)

CEO tenure is operationalized as the number of years the executive has been CEO (e.g., Finkelstein \& Hambrick, 1989)

Measures total numbers of directors who serve on the board (e.g., Staw \& Epstein, 2000)

A variable that reflects the degree to which the board of directors operates independently from corporate insiders, commonly measured as the ratio of outside board members to the total number of board members (e.g., Berrone \& Gomez-Mejia, 2009)

Measures the extent to which the firm's outstanding stock is in the hands of large block holders and reflects the percentage of the firm's ownership held by those who own at least 5\% of the firm's outstanding shares (e.g., Grossman \& Cannella, 2006)

This variable represents the equity position held by all institutional investors and assumes a positive value (either 1 in the case of dummy operationalizations or a percentage in case the degree of institutional owners is known) when the owner is an institutional investor (e.g., public or company pension funds, mutual funds, insurance services; e.g., David et al., 1998)

An indicator of the size of the firm, commonly measured as a firm's total assets, sales, or employees (e.g., Finkelstein \& Hambrick, 1989)

A variable that reflects the degree of leverage of the firm, commonly measured as ratio of total debts to total assets (e.g., Grossman \& Cannella, 2006)

A variable that reflects the degree to which firms are simultaneously active in many different businesses (entropy index, Herfindahl index, or number of segments; e.g., Carpenter, Sanders, \& Gregersen, 2001)

A variable that reflects the degree to which the financial valuation of a firm's stock varies in relation to movements of the broader market; a commonly used measure of such risk is the beta of a firm's stock, computed by regressing a firm's monthly stock return on the corresponding country's market index return (e.g., J. S. Miller, Wiseman, \& Gomez-Mejia, 2002) 
Table 2 (continued)

\begin{tabular}{ll}
\hline Variable & \multicolumn{1}{c}{ Description } \\
\hline Firm R\&D & A variable that reflects the degree of R\&D expenditures of the firm, commonly \\
& measured as the ratio of research and development expenditure to total sales (e.g., \\
Carpenter et al., 2001) & Measured as the number of years (e.g., Attaway, 2000) \\
CEO age & Measures the extent to which a firm's outstanding stock is in the hands of directors \\
Inside ownership & and officers (e.g., Grossman \& Cannella, 2006) \\
&
\end{tabular}

hypotheses because it allows us to analyze the direct effect of our indicators of managerial and director power on CEO total compensation. We used MASEM to avoid biased estimates resulting from possible correlations among independent variables. This can be a problem if the standard HOMA approach (Hedges \& Olkin, 1985) is used by itself. We conducted our structural equation modeling by using a two-stage procedure (Carney et al., 2011).

In the first stage, we used HOMA to compute the meta-analytic Pearson product-moment correlation $(r)$ between independent and dependent variables as well as the corresponding confidence interval. This produced a meta-analytic correlation table. Since HOMA procedures assume that effect sizes are normally distributed, we used Fisher's (1928) $Z r$ transformation to correct for possible skewness in the effect size distribution (Hedges \& Olkin, 1985). ${ }^{1}$ In line with current conventions among meta-analytic researchers, we used random effects HOMA for combining study estimates (Geyskens, Krishnan, Steenkamp, \& Cunha, 2009). ${ }^{2}$ To estimate the mean effect size appropriately, differences in precision across effect sizes had to be accounted for, so we weighted effect sizes by their inverse variance weight $(w)$, that is, the inverse of their squared standard error (Hedges \& Olkin, 1985). ${ }^{3}$ We also used these weights to calculate the standard error of the mean effect size and its confidence interval. ${ }^{4}$

In the second stage, this meta-analytic correlation matrix was treated as the observed correlation matrix and subjected to regular maximum likelihood structural equation modeling routines to test the aforementioned hypotheses (Cheung \& Chan, 2005). In this procedure, the harmonic mean number of observations from all studies was treated as the number of observations. In this way, correct and conservative $t$ values for the model parameters were estimated (Geyskens, Steenkamp, \& Kumar, 2006). The data were analyzed using the full information maximum likelihood method with the LISREL 8.80 software package.

\section{MARA Procedure}

We tested Hypotheses 1b, 2b, 3b, 4b, 5b, and 6b using MARA (Lipsey \& Wilson, 2001). In our MARA analyses, the dependent variable is neither pay nor performance but an estimate of the associational strength of the focal relationship (i.e., the relationship between performance and pay) in a given sample. We use partial correlation coefficients $\left(r_{x y: z}\right)$ as our effect size estimates for the MARA procedure, and in our case it captures the association between firm performance and CEO total compensation, given a set of $n$ control variables. 
It can be computed from the $t$ statistics and degrees of freedom reported in primary studies (Greene, 2008). ${ }^{5}$ Similar to multiple regression approaches, MARA analyses construct a linear regression model involving a set of predictors, which in this case are the potential moderators of the performance-pay relationship (i.e., managerial power variables and our control variables) on the dependent variable (i.e., the effect size). We weighted these effect sizes by their inverse variance weight to account for differences in the precision of the information contained in them (Aguinis, Gottfredson, \& Wright, in press). In other words, the primary-level study effect sizes are regressed onto a set of predictors (i.e., moderators) of the performance-pay relationship (Carney et al., 2011; Doucouliagos \& Ulubaşoğlu, 2008; Lipsey \& Wilson, 2001; Stanley \& Jarrell, 2005). Following current standards in the metaanalytic literature (Geyskens et al., 2009), we used random effects estimation methods in our MARA analyses, which are more conservative than conventional fixed effects methods. Specifically, this yielded the following regression equation,

$$
R_{i}=\mathrm{y}_{0}+\mathrm{y}_{\mathrm{m}} \mathrm{D}_{i}+\beta_{\mathrm{m}} \mathrm{S}_{i}+\varphi \mathrm{R}_{I}+u_{i}
$$

where $R_{i}$ is the partial correlation between firm performance and CEO total compensation, $\mathrm{y}_{0}$ is the constant term, $\mathrm{D}$ is a vector of whether a particular variable is included in a regression or not, $\mathrm{S}$ is a vector of measurement artifacts, $\mathrm{R}$ is a vector of study characteristics, and $u_{i}$ is the random component.

To test the moderating effects of the indicators of CEO and board power on the performance-pay relationship, we included in the $\mathrm{D}$ vector a set of dummy variables indicating whether the following variables were included in the regression (0) or not (1): CEO duality, CEO tenure, board size, board independence, ownership concentration, and institutional ownership. We also included dummy variables indicating whether the following control variables were included in the regression (0) or not (1): firm size, firm risk, firm diversification, firm R\&D level, firm debt level, CEO age, and inside ownership.

To control for the influence of measurement artifacts on effect sizes, we included in the $\mathrm{S}$ vector several control variables. More specifically, to test for the moderating effect of focal variable operationalizations, we added dummy variables indicating whether firm performance was measured as accounting (1) or as market (0) performance and whether the effect size was derived from a study investigating changes in performance and changes in compensation (1) or was derived from a study investigating absolute levels of performance and compensation (0). To test for the moderating effect of methodological artifacts, we included a dummy variable indicating whether a given effect size was based on panel (1) or cross-sectional (0) data. We also included a dummy variable coded as (1) when an effect size was derived from a study controlling for the possible endogeneity of firm performance on executive compensation and as (0) otherwise. ${ }^{6}$ In addition, we controlled for the number of variables in the regression and whether a study controlled for year and industry effects. To control for the influence of study artifacts, we included in the $\mathrm{R}$ vector three other control variables. To test for the "file drawer problem" (Rosenthal, 1979), we included a dummy variable denoting whether a study was published (1) or not (0). To control for the possibility that the focal relationship weakened or strengthened over time (Gregg, Machin, \& Szymanski, 1993), we 
added the median year of the sample window. Finally, we included each publication's 5-year ISI impact factor to control for publication outlet status effects (Carney et al., 2011).

\section{Results}

\section{CEO Total Compensation}

Tables 3 and 4 report the results pertaining to Hypotheses 1a, 2a, 3a, 4a, 5a, and $6 a$. Table 3 depicts the meta-analytic correlation matrix. The cells below the diagonal represent 105 separate HOMA meta-analyses and report the meta-analytic mean correlation for each relationship, which we use to run the MASEM analyses. Above-diagonal cells report the number of observations $(N)$ and the number of samples $(k)$ on which the meta-analytic mean is based. Table 4 contains MASEM results. The model fits the data well $\left(\chi^{2}=1,205.77\right.$, root mean square error of approximation [RMSEA] $=.09$, root mean square residual $[\mathrm{RMSR}]=.03)$.

Hypothesis 1a, which predicts that CEO duality is positively related to the level of total CEO compensation, is confirmed by the results in Table 4. We find that CEO duality is positively related to CEO total pay $(\beta=.02, p<.05)$. We find no support for Hypothesis $2 \mathrm{a}$ that $\mathrm{CEO}$ tenure is positively related to CEO compensation levels $(\beta=-.00, p>.05)$. We find clear support for Hypothesis $3 \mathrm{a}$, as the size of boards is associated with higher levels of total pay $(\beta=.12, p<.01)$. In fact, after firm size, board size has the largest impact on total pay. In contrast to the prediction of Hypothesis $4 \mathrm{a}$, the degree of board independence is positively related to total pay levels $(\beta=.06, p<.01)$. Our findings also provide support for Hypothesis 5a: As hypothesized, concentrated ownership is negatively related to the level of total CEO compensation $(\beta=-.04, p<.01)$. Finally, we find support for Hypothesis 6 a that the presence of higher levels of institutional ownership is associated with lower levels of total pay $(\beta=-.03, p<.01)$.

Table 4 also reports the results for the control variables. We find that firm performance $(\beta=.12, p<.01)$, firm size $(\beta=.28, p<.01)$, firm diversification $(\beta=.02, p<.05)$, firm risk $(\beta=.11, p<.01)$, and firm $\mathrm{R} \& \mathrm{D}$ level $(\beta=.03, p<.01)$ are all positively related to total CEO compensation. However, firm debt level $(\beta=-.10, p<.01)$, CEO age $(\beta=-.06, p<$ $.01)$, and inside ownership $(\beta=-.02, p<.05)$ are all negatively related to total pay levels. The results confirm previous research that firm size is the most important antecedent variable to explain CEO total compensation (Tosi et al., 2000).

In Appendices B, C, and D we report the HOMA results of the levels of both total CEO compensation and a breakdown of the levels of other pay components of CEO compensation (i.e., salary, cash bonus, total cash, and LTIPs) in relationship to board and CEO characteristics (Appendix B), ownership concentration and institutional ownership (Appendix C), and firm performance (Appendix D). We present the HOMA results in two panels. Panel 1 contains a set of $r$-based HOMA results (Pearson product-moment correlations), and Panel 2 contains the corresponding $r_{x y . z}$-based HOMA findings (partial correlations). In addition to the metaanalytic mean $(M)$, we report the number of samples $(k)$, the total sample size $(N)$, the 


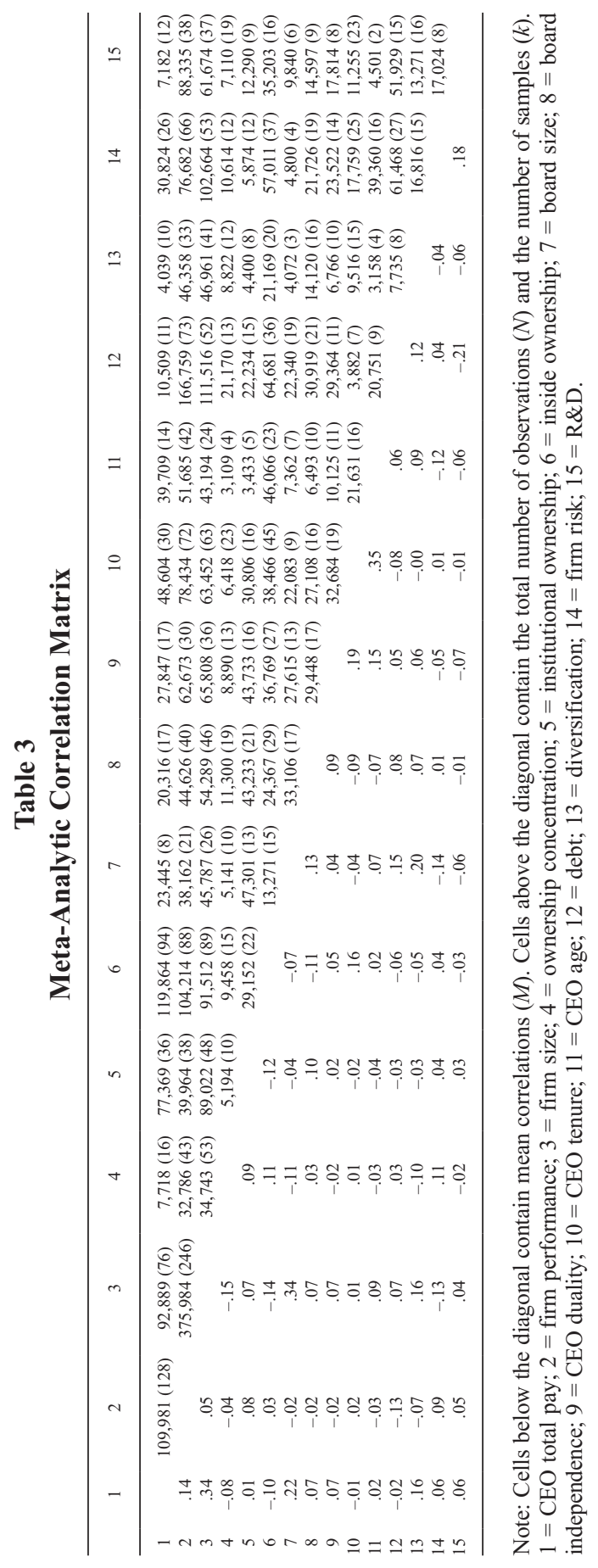


Table 4

Meta-Analytic Structural Equation Modeling Results

\begin{tabular}{lcr}
\hline & & CEO Total Pay \\
\cline { 2 - 3 } Predictor & \multicolumn{1}{c}{$\beta$} & \multicolumn{1}{c}{$t$} \\
\hline CEO duality & $.02^{*}$ & 1.82 \\
CEO tenure & -.00 & -0.29 \\
Board size & $.12^{* *}$ & 14.46 \\
Board independence & $.06^{* *}$ & 3.09 \\
Ownership concentration & $-.04^{* *}$ & -4.24 \\
Institutional ownership & $-.03^{* *}$ & -3.69 \\
Firm performance & $.12^{* *}$ & 15.68 \\
Firm size & $.28^{* *}$ & 33.76 \\
Firm debt level & $-.10^{* *}$ & -10.23 \\
Firm diversification & $.02^{*}$ & 2.10 \\
Firm risk & $.11^{* *}$ & 13.97 \\
Firm R\&D level & $.03^{* *}$ & 3.21 \\
CEO age & $-.06^{* *}$ & -7.88 \\
Inside ownership & $-.02^{*}$ & -2.23 \\
Harmonic mean $N$ & 14,349 & \\
$\chi^{2}$ & $1,205.77$ & \\
RMSEA & .09 & \\
RMSR & .03 & \\
\hline
\end{tabular}

${ }^{*} p<.05 .{ }^{* *} p<.01$.

standard error of the mean effect size (SE), Cochran's homogeneity test statistic ( $Q$ test), ${ }^{7}$ and the explained variance (EV). When a blank line appears in a table, it is because there were not enough effect sizes available to estimate the particular relationship. In addition to these results, we ran different robustness checks (not reported) on subsets of our data to investigate possible time and primary study sampling effects. These tests revealed similar results as the results reported here. ${ }^{8}$

\section{Performance-Pay Sensitivity}

Table 5 presents the MARA results, which relate to Hypotheses $1 b, 2 b, 3 b, 4 b, 5 b$, and $6 b$. In the MARA analyses, the dependent variable is neither pay nor performance but the partial correlation between firm performance and CEO total compensation. We report in Table 5 the effect of studies that fail to control for each specific indicator of CEO or board power relative to those studies that do control for a specific indicator. For example, some studies do not control for board independence in their regression analyses whereas others do. Therefore, if we report a positive and significant coefficient for a variable, this indicates that studies that did not include this variable reported a stronger relationship between firm performance and CEO total compensation than studies that did control for the variable. Hence, this variable has a positive moderation effect on the focal relationship. We also analyzed the effects of a number of control variables in the same way. Overall, the model fits the data reasonably well $\left(R^{2}=.27\right)$. 
Table 5

MARA Partial Correlation Coefficient Results ${ }^{\mathrm{a}, \mathrm{b}}$

\begin{tabular}{|c|c|}
\hline Variable & Model (1) \\
\hline \multicolumn{2}{|l|}{ Managerial power indicators } \\
\hline CEO duality & $0.00(0.01)$ \\
\hline CEO tenure & $-0.04(0.01)^{* *}$ \\
\hline Board size & $0.06(0.02)^{* *}$ \\
\hline Board independence & $0.03(0.01)^{* *}$ \\
\hline Ownership concentration & $0.01(0.01)$ \\
\hline Institutional ownership & $0.03(0.01)^{*}$ \\
\hline \multicolumn{2}{|l|}{ Control variables } \\
\hline Firm size & $0.03(0.01)^{*}$ \\
\hline Firm risk & $0.01(0.01)$ \\
\hline Firm diversification & $0.03(0.02)$ \\
\hline Firm R\&D level & $0.02(0.02)$ \\
\hline Firm debt level & $-0.02(0.02)$ \\
\hline CEO age & $0.01(0.01)$ \\
\hline Inside ownership & $-0.02(0.01)$ \\
\hline \multicolumn{2}{|l|}{ Focal variable operational } \\
\hline Accounting performance & $-0.07(0.01)^{* *}$ \\
\hline Change variables used & $-0.04(0.01)^{* *}$ \\
\hline \multicolumn{2}{|l|}{ Methodological artifacts } \\
\hline Panel design & $-0.01(0.01)$ \\
\hline Endogeneity check & $0.00(0.00)$ \\
\hline Number of variables in regression & $0.00(0.00)$ \\
\hline Control year effect & $0.02(0.01)^{*}$ \\
\hline Control industry effect & $-0.04(0.01)^{* *}$ \\
\hline \multicolumn{2}{|l|}{ Study artifacts } \\
\hline Published & $0.03(0.01)^{*}$ \\
\hline Median year sample window & $-0.00(0.00)$ \\
\hline Five-year ISI impact factor & $0.00(0.00)$ \\
\hline $\mathrm{R}^{2}$ & 0.27 \\
\hline $\mathrm{K}$ & 554 \\
\hline $\mathrm{Q}_{\text {Model }}(p)$ & $244.86(0.00)^{* *}$ \\
\hline $\mathrm{Q}_{\text {Residual }}(p)$ & $673.89(0.00)^{* *}$ \\
\hline $\mathrm{V}$ & 0.00391 \\
\hline
\end{tabular}

anstandardized regression coefficients are presented for study moderators and substantive moderators with standard errors in parentheses. $k$ is the total number of effect sizes; $Q$ is the homogeneity statistic with its probability in parentheses; $v$ is the random effects variance component.

$\mathrm{b} * p<.05 * * p<.01$.

The MARA results, as reported in Table 5, do not provide support for Hypothesis $1 \mathrm{~b}$. CEO duality has no significant moderating effect on the performance-pay relationship. We find support for Hypothesis $2 \mathrm{~b}$, which predicts that the presence of CEOs with longer tenure negatively moderates the performance-pay relationship. The results show that studies that fail to control for CEO tenure in their regression analyses find a weaker performance-pay relationship (Doucouliagos \& Ulubaşoğlu, 2008). Hence, in the presence of CEOs with 
longer tenure, the association between firm performance and CEO compensation becomes weaker. In contrast to Hypothesis $3 \mathrm{~b}$, we find that in the presence of larger boards, the association between firm performance and CEO compensation actually becomes stronger. We find support for Hypothesis 4, that board independence positively moderates the performance-pay relationship. However, we find no moderating effect of ownership concentration on the performance-pay relationship, as hypothesized by Hypothesis $5 \mathrm{~b}$. Finally, we find support for Hypothesis $6 \mathrm{~b}$, as institutional ownership positively moderates the performance-pay relationship.

In terms of our control variables, the only significant finding was a positive effect for the firm size variable, which suggests that firm size positively moderates the performance-pay relationship. In terms of the indicators that measure the operationalizations of specific variables, we find a negative significant result for compensation changes to performance changes, which indicates that studies using absolute levels of compensation tend to identify stronger performance-pay relationships than those using changes in the levels of performance and compensation. We also find a negative effect for accounting performance, implying that studies that use accounting-based measures tend to find weaker performance-pay relationships than studies that use market-based measures as indicators for firm performance. Of the methodological moderators, our findings suggest that studies that control for the effects of time show stronger associations between firm performance and CEO compensation and studies that control for industry effects tend to find weaker associations. Finally, in terms of study artifacts, the significant positive effect for the published variable indicates that the "file drawer problem" (Rosenthal, 1979) is present in the executive pay field, implying that studies reporting greater effects have a better chance of being published.

As a robustness check of the MARA results, we examined the effects of the indicators of CEO and board power on the proportion of LTIPs to total compensation using the HOMA procedure. Examining the proportion of LTIPs relative to total compensation serves as a robustness check for our analyses of performance-pay sensitivities because LTIPs are usually based on firm performance. Therefore, the proportion of LTIPs to total compensation can be seen as an indicator of how performance and total pay are linked. Similar to the performance-pay sensitivities analyzed in the MARA results, we expect that more powerful CEOs will have a lower proportion of LTIPs to total compensation. In contrast, we expect that stronger boards will be associated with higher proportions of LTIPs. Appendix E presents the HOMA results, and as expected, they are identical to those of the MARA results in terms of their direction and statistical significance.

\section{Discussion}

Over the past decade, MPT has generated productive debates about the determinants of executive compensation by challenging the core assumption of agency theory that executive pay is set through arm's-length contracting between executives and boards of directors (Bebchuk \& Fried, 2004). Although MPT has been provocative, the empirical evidence has been mixed, allowing both proponents and opponents of MPT to argue in favor of and against it (O'Reilly \& Main, 2010). In this article, we used a range of meta-analytic techniques to consolidate the often mixed empirical findings of 219 studies and provide a more definitive 
Table 6

Summary of Predictions and Results

\begin{tabular}{lccccc}
\hline & \multicolumn{2}{c}{ Total Pay } & & \multicolumn{2}{c}{$\begin{array}{c}\text { Performance-Pay } \\
\text { Sensitivity }\end{array}$} \\
\cline { 2 - 5 } Indicator of Power & Predicted & Actual & & Predicted & Actual \\
\cline { 2 - 5 } CEO duality (Hypothesis 1) & + & + & - & $n s$ \\
CEO tenure (Hypothesis 2) & + & + & - & - \\
Board size (Hypothesis 3) & + & + & - & + \\
Board independence (Hypothesis 4) & - & - & + & $n s$ \\
Ownership concentration (Hypothesis 5) & - & - & + & + \\
Institutional ownership (Hypothesis 6) & - & & & + \\
\hline
\end{tabular}

assessment than those reported in any single primary study (C. C. Miller \& Cardinal, 1994). In this section, we describe the contributions of our study and discuss avenues for future research.

\section{Implications for Managerial Power Theory}

Our tests of MPT focused on examining firm-level relationships between six different measures of managerial power and two outcomes: CEO total compensation levels and performance-pay sensitivities. We find support for MPT, but our findings do not allow us to say unequivocally that MPT holds across all conditions. Table 6 summarizes our predictions and findings.

In assessing the evidence regarding the relationship between managerial power and total compensation levels, we find overall support for MPT. Two of the three indicators of CEO power (board size and CEO duality) are positively associated with total pay, suggesting that in most situations where CEOs are expected to have more power over the pay setting process, they have higher levels of total compensation. Similarly, two out of the three indicators of board power (ownership concentration and institutional ownership) are negatively associated with total pay, suggesting that in most situations where boards have more power over the pay setting process, CEOs have lower total compensation. The two exceptions to these patterns are that board independence is positively associated with total compensation and the effect of CEO tenure is not significantly related to total compensation.

The results for performance-pay sensitivities provide less support for MPT. Only one of the indicators of CEO power (CEO tenure) is statistically significant and in the expected negative direction, whereas CEO duality is not significant, and board size is significant but in the opposite (positive) direction. However, two out the three indicators of board power (board independence and institutional ownership) are significant and in the expected positive direction, but ownership concentration is not significant. These results suggest that MPT is better able to explain total pay levels than performance-pay sensitivities. They further suggest that even powerful CEOs have a difficult time mitigating the performancepay link. 
Our total compensation measure may, however, obscure variation in the effects of the indictors of $\mathrm{CEO}$ and director power on different forms of compensation. For example, since CEOs may, like most employees, tend to prefer less risky forms of compensation, it is likely that powerful CEOs will have higher levels of cash compensation and have less pay at risk, such as LTIPs (Conyon \& Murphy, 2000). To further examine the ability of MPT to account for the influence of CEO and board power on the level of different types of executive compensation, we ran additional MASEM models with the value of total cash compensation and LTIPs as dependent variables (see Appendix F). We find that all three of the indicators of CEO power are associated with higher levels of total cash compensation, whereas only one of the indicators of board power (ownership concentration) is associated with lower levels of total cash compensation. Two other indicators of board power, board independence and institutional ownership, are insignificantly related. Turning to LTIPs, the results reveal that two out of the three indicators of board power (ownership concentration and institutional ownership) are associated with higher levels of LTIPs, whereas board independence is negatively related. Two out of three indicators of CEO power (board size and CEO duality) are also associated with higher levels LTIPs, whereas CEO tenure is negatively related. These results suggest that powerful CEOs have more influence over setting cash compensation levels (even over more powerful boards) and powerful boards have more influence over linking pay to performance (even over powerful CEOs). These supplementary results suggest a more nuanced version of MPT in which different types of actors are able to use their power to influence different types of executive compensation outcomes.

Overall, the meta-analytic evidence reveals that MPT is well equipped for explaining levels of total cash and total compensation but less so for explaining pay at risk and performance-pay sensitivity. Although powerful CEOs seem well positioned to realize higher levels of cash compensation, powerful directors seem to be able to negotiate for higher levels of pay at risk and tighter links between firm performance and CEO compensation. Moreover, the findings suggest that directors can realize these preferences even in the face of powerful CEOs. This is contrary to what MPT predicts and is evidence that executives are not able to use their power unilaterally to influence all outcomes in their favor.

One possible explanation for director power with respect to pay at risk lies in the broader acceptance of the practice of linking pay to performance that emerged during the $1990 \mathrm{~s}$, the sample period of most of the studies in our meta-analyses. During this period, LTIPs were increasingly considered more appropriate by shareholders, who became more interested in making links between performance and pay (Zajac \& Westphal, 2004), and even among some executives who saw them as another potential mechanism of wealth generation (Bebchuk \& Fried, 2004). The institutionalization of practices such as stock options and other forms of LTIPs during this period might have provided directors a solid foundation from which to negotiate, even in the face of powerful CEOs.

An alternative explanation for why we did not find a negative effect of our CEO power indicators on performance-pay sensitivities is that the incentives of directors and CEOs for performance-pay relationships may have actually been aligned, that is, some CEOs may have preferred more performance-pay sensitivity. Such a preference could have been the result of the increased acceptance of such practices noted above, or, since preferences for and perceptions of risk may vary across individuals (Pablo, 1997; Sanders, 2001), it could 
have been the result of some executives preferring riskier arrangements or misperceiving the riskiness of their arrangements.

Yet another explanation for the observed variation in the settings where CEOs and directors seem to be able to wield power could lie in the very nature of negotiation itself. Given that both executives and directors want to achieve their objectives but may not be able to obtain everything they seek, the ultimate result may be that although powerful CEOs end up with higher pay levels, they have to accept that their pay is to some extent at risk and more sensitive to performance. This may reflect a payoff in which executives are compensated for taking on other forms of riskier compensation and indicate that executives and directors arrive at solutions in which they both realize some of their objectives. ${ }^{9}$

Ultimately, our data do not allow us to adjudicate between these and other possible explanations, but the findings highlight the necessity of future research to pay close attention to analyzing the influence of managerial and director power on different types of pay, the preferences of different parties for different forms of pay, and the ratio of pay at risk to total compensation as a dependent variable. The latter would also allow us to better understand the relative importance and implications of pay at risk, which remain understudied (Murphy, 1999).

It is important to note the results that diverge from our primary interpretation. Board power measured by board independence, for example, is influential only in the case of performance-pay sensitivities. More independent boards appear to strengthen performancepay relationships, but they do not appear to be able to limit the level of cash compensation, nor increase the level of LTIPs. One possible explanation is that independence may be an imprecise measure of board power. Independent directors, for example, may be prone to CEO influence because of the role of CEOs in director selection, the bonds of shared interests and collegiality among board members, and their dependence on executives for information (Bebchuk \& Fried, 2004). In addition, independent directors are often outsiders who have limited inside information on the firm or on the day-to-day operations of its chief executive. For them, the choice between monitoring behavior and rewarding outputs may be decided in favor of the latter, as direct monitoring is less practical for them. This highlights the need for future research to develop better theoretical conceptualizations and measures of board independence.

The findings for CEO tenure also diverge from the overall pattern. Tenure is negatively associated with levels of LTIPs and lower performance-pay sensitivity, contrary to our main findings that powerful CEOs have a difficult time negotiating for exactly these outcomes. A reasonable interpretation of this is that CEOs with longer tenure are closer to retirement and that boards recognize this and may reduce longer-term incentives, focusing more on cash and shorter term incentives (Nourayi \& Mintz, 2008). This may also explain why we do not find a significant positive association between CEO tenure and total compensation but do find a significant positive association with total cash compensation. Another explanation could be that CEO power increases cash compensation because extended tenure prevents CEOs from receiving higher pay that is associated with the premiums paid by hiring firms to motivate CEOs to give up their firm-specific human capital and take on the risk of moving to another firm where they lack this kind of capital (Harris \& Helfat, 1997). 


\section{Limitations and Other Avenues for Future Research}

Obviously, our analysis has limitations, the most important of which are related to available research on executive compensation and to our analytical approach. The first is the somewhat problematic interpretation of certain indicators as proxies for managerial or director power. Most research has focused on formal board attributes, ownership structures, and CEO characteristics as measures of relative managerial power. These measures are much easier to observe than others that might have more validity, such as the actual decision-making processes of boards and how CEOs might actually influence these decisions. Although some research has moved beyond collecting and analyzing easily accessible secondary data by collecting primary data (e.g., O'Reilly \& Main, 2010; Westphal \& Stern, 2007) and by combining these with secondary data (e.g., McDonald, Khanna, \& Westphal, 2008), clearly much work remains to be done.

A related criticism of our approach is that a large study of original data could be a better way to test MPT than a meta-analysis. Given the mixed results in primary studies and the debates in the literature, however, meta-analysis is an appropriate way to assess the evidence from a large group of studies (Dalton et al., 2003; C. C. Miller \& Cardinal, 1994). In addition, our meta-analytic assessment allows us also to identify avenues for future research to advance our understanding based on the cumulated evidence. Using primary data, however, would be another fruitful avenue for testing MPT as well as for identifying other determinants of executive compensation and further theory development.

Another limitation of our analysis is that the majority of studies included in our sample have relied on data drawn from samples of large U.S. corporations, such as the S\&P 500, and may not be generalizable beyond this sample (Dalton et al., 2003; Deutsch, 2005). Although much of the attention in management, accounting, economic, and finance research has focused on this population of large corporations, they actually compose a very small percentage of total business enterprises. However, their visibility and size make them an important group of organizations for testing theories of corporate governance. An important way in which MPT could be extended, however, would be to move beyond this group of firms to focus on cross-national variation in institutional and cultural constraints on managerial power. This has only recently started to attract the attention of pay researchers (Tosi \& Greckhamer, 2004) and is clearly missing from most of the literature on MPT.

In addition, to be able to assess our predicted relationships through meta-analysis, we required a large enough sample of effect sizes, which naturally limited the number of variables we could test. There are likely some measures of managerial power that we could not include that would have strengthened our analysis, such as board interlocks. Moreover, some researchers have suggested that the relationships between managerial power and CEO pay are nonlinear (Devers et al., 2007; Finkelstein \& Hambrick, 1989). Since the number of studies investigating these relationships is relatively limited, we were unable to include this in our analyses. As such, future research should attend to examining the roles that nonlinear relationships and other proxies for power could play in furthering our understanding of the links between managerial power and executive compensation outcomes.

Finally, it is important to highlight the relatively small percentage of variance explained by indicators of CEO and board power. Our findings show that firm size is far more important for explaining CEO compensation (Tosi et al., 2000). Relative to significant indicators of 
CEO and board power, the mean correlation between CEO total compensation and firm size is about 2 to 14 times higher, depending on the indicator. Overall, MPT indicators show a modest relationship with CEO total compensation and performance-pay sensitivity. Our findings are, however, in line with other meta-analyses that find that board and ownership structures do not explain a great deal of variance in firm strategy (Deutsch, 2005; van Essen et al., in press) and firm performance (Dalton et al., 1998; Dalton et al., 2003; Heugens et al., 2009; van Essen et al., in press). Finally, other meta-analyses have found similar results for the influence of CEO duality on strategy (van Essen et al., in press) and firm performance (Rhoades, Rechner, \& Sundaramurthy, 2001).

\section{Conclusion}

Research on executive compensation continues to be divided along disciplinary lines regarding whether pay is set through optimal contracting arrangements or whether managerial power over directors compromises these arrangements. The meta-analytic evidence presented here represents strong evidence that managers can and do influence their pay arrangements and that their power can be constrained by shareholders and their agents. However, the results are also clear that MPT does not provide a single unifying explanation for all executive compensation outcomes, particularly regarding arrangements that link pay to performance. In these cases, directors appear to have the upper hand over powerful CEOs. Managerial power, therefore, has an important influence over the pay-setting process, but optimal contracting arrangements may also exist. MPT and optimal contracting, therefore, do not represent competing explanations but describe points on a continuum of types of contracting arrangements that can be encompassed within agency theory. We hope that the evidence presented here helps other scholars move debates about the determinants of executive compensation away from stylized representations of MPT and optimal contracting to more nuanced and multidisciplinary approaches that pay careful attention to measuring the phenomena of interest. Indeed, research designs that permit more precise measurement of executive influence over the pay-setting process (e.g., O’Reilly \& Main, 2010) can help us develop a more expansive theory of agency (Wiseman, Cuevas-Rodriguez, \& Gomez-Mejia, in press). Ultimately, the research to date shows that MPT represents one such useful expansion of agency theory.

Appendix A

Studies Included in the Meta-Analysis

\begin{tabular}{lcc}
\hline Author & Year & Publication \\
\hline Agarwal & 1981 & $I R$ \\
Agrawal and Knoeber & 1998 & $J F E$ \\
Ahn and Han & 2008 & WP \\
Al-Shammari & 2008 & WP \\
Anderson, Becher, and Campbell & 2004 & $J F I$ \\
Anderson, Banker, and Ravindran & 1999 & WP \\
Ang, Lauterbach, and Schreiber & 2002 & $J B F$ \\
Angbazo and Narayanan & 1997 & EFR \\
Ashley and Yang & 2004 & $J B E$ \\
Attaway & 2000 & $A B R$ \\
Baber, Kang, and Kumar & 1998 & $J A E$ \\
\hline
\end{tabular}


Appendix A (continued)

\begin{tabular}{|c|c|c|}
\hline Author & Year & Publication \\
\hline Baber, Kang, and Kumar & 1999 & $A R$ \\
\hline Baber, Kang, and Liang & 2006 & WP \\
\hline Baecker & 2008 & $\mathrm{CH}$ \\
\hline Baker, Collins, and Reitenga & 2002 & WP \\
\hline Balkin, Markman, and Gomez-Mejia & 2000 & $A M J$ \\
\hline Banning & 2004 & $\mathrm{COC}$ \\
\hline Banning and Chiles & 2007 & $J L R$ \\
\hline Barro and Barro & 1990 & $J L E$ \\
\hline Bartkus, Morris, and Seifert & 2002 & $B S$ \\
\hline Beatty and Zajac & 1994 & $A S Q$ \\
\hline Bebchuk and Grinstein & 2007 & WP \\
\hline Belliveau, O'Reilly, and Wade & 1996 & $A M J$ \\
\hline Berrone and Gomez-Mejia & 2009 & $A M J$ \\
\hline Bhattacharyya, Mawani, and Morrill & 2008 & $A F$ \\
\hline Bilimoria & 1997 & $H R$ \\
\hline Bliss and Rosen & 2001 & $J F E$ \\
\hline Boschen, Duru, Gordon, and Smith & 2003 & $A R$ \\
\hline Boumosleh & 2008 & WP \\
\hline Bovie & 2008 & WP \\
\hline Bowen, Rajgopal, and Venkatachalam & 2003 & WP \\
\hline Boyd & 1994 & SMJ \\
\hline Brander & 2006 & $J B E$ \\
\hline Brick, Palmon, and Wald & 2006 & $J C F$ \\
\hline Bryan, Hwang, and Lilien & 2000 & $J B$ \\
\hline Bryan and Klein & 2004 & WP \\
\hline Buchholtz, Young, and Powell & 1998 & $G O M$ \\
\hline Byrd and Hickman & 1995 & $M F$ \\
\hline Campbell, Johnston, Sefcik, and Soderstrom & 2007 & $J A P P$ \\
\hline Carpenter & 2000 & $J M$ \\
\hline Carpenter and Sanders & 2004 & $J M$ \\
\hline Carpenter, Sanders, and Gregersen & 2001 & $A M J$ \\
\hline Carpenter and Seo & 2004 & WP \\
\hline Carr & 1997 & $J S B M$ \\
\hline Carter, Lynch, and Tuna & 2007 & $A R$ \\
\hline Certo, Daily, Cannella, and Dalton & 2003 & $A M J$ \\
\hline Cheng & 2004 & $A R$ \\
\hline Cheng, Collins, and Huang & 2006 & WP \\
\hline Cheng and Indjejikian & 2009 & $\operatorname{IRLE}$ \\
\hline Ciscel & 1974 & SEJ \\
\hline Ciscel and Carroll & 1980 & RES \\
\hline Collins, Reitenga, and Sanchez-Cuevas, & 2004 & WP \\
\hline Combs, Ketchen, Perryman, and Donahue & 2007 & $J M S$ \\
\hline Conyon & 2006 & $A M P$ \\
\hline Conyon, Peck, and Sadler & 2009 & $A M P$ \\
\hline Coombs and Gilley & 2005 & SMJ \\
\hline Cordeiro & 2005 & WP \\
\hline Cordeiro and Veliyath & 2003 & $A B R$ \\
\hline Core, Holthausen, and Larcker & 1999 & $J F E$ \\
\hline Daily, Johnson, Ellstrand, and Dalton & 1998 & $A M J$ \\
\hline David, Hitt, and Gimeno & 2001 & $A M J$ \\
\hline David, Kochhar, and Levitas & 1998 & $A M J$ \\
\hline Davidson, Xie, $\mathrm{Xu}$, and Ning & 2007 & $J M G$ \\
\hline Davila and Penalva & 2006 & $R A S$ \\
\hline Davila and Venkatachalam & 2004 & $R A S$ \\
\hline
\end{tabular}


Appendix A (continued)

\begin{tabular}{|c|c|c|}
\hline Author & Year & Publication \\
\hline Deckop & 1988 & ILRR \\
\hline Deckop, Merriman, and Gupta & 2006 & $J M$ \\
\hline Deutsch, Keil, and Laamanen & 2007 & $J M$ \\
\hline Dikolli, Kulp, and Sedatole & 2005 & WP \\
\hline Dorata and Petra & 2008 & $M F$ \\
\hline Duru and Reeb & 2002 & $J A A F$ \\
\hline Duru and Smith & 2001 & WP \\
\hline Elhagrasey, Harrison, and Buchholz & 1999 & $J M G$ \\
\hline Elyasiani and Jia & 2007 & WP \\
\hline Ertugrul, Sezer, and Sirmans & 2008 & JREFE \\
\hline Fahlenbrach & 2008 & $R F$ \\
\hline Feng, Gramlich, and Gupta & 2006 & WP \\
\hline Fich and Slezak & 2008 & $R Q F A$ \\
\hline Finkelstein and Boyd & 1998 & $A M J$ \\
\hline Finkelstein and Hambrick & 1989 & $S M J$ \\
\hline Frey, Nelling, and Webb & 2006 & CGIR \\
\hline Garvey and Milbourn & 2003 & $J F$ \\
\hline Garvey and Milbourn & 2006 & $J F E$ \\
\hline Geiger and Cashen & 2007 & $J M I$ \\
\hline Geletkanycz, Boyd, and Finkelstein & 2001 & $S M J$ \\
\hline Ghosh and Sirmans & 2005 & JREFE \\
\hline Gibbons and Murphy & 1990 & ILRR \\
\hline Gomez-Mejia, Larraza-Kintana, and Makri & 2003 & $A M J$ \\
\hline Gomez-Mejia, Tosi, and Hinkin & 1987 & $A M J$ \\
\hline Goranova, Alessandri, Brandes, and Dharwadkar & 2007 & SMJ \\
\hline Gottesman and Morey & 2006 & WP \\
\hline Gray and Cannella & 1997 & $J M$ \\
\hline Grossman and Cannella & 2006 & $J M$ \\
\hline Hall and Liebman & 1998 & QJE \\
\hline Hallock & 1997 & $J F Q A$ \\
\hline Hambrick and Finkelstein & 1995 & SMJ \\
\hline Harjoto and Mullineaux & 2003 & $J F R$ \\
\hline Harris and Helfat & 1997 & $S M J$ \\
\hline Haushalter & 2000 & $J F$ \\
\hline $\mathrm{He}$ & 2008 & $J B V$ \\
\hline $\mathrm{He}$ & 2008 & WP \\
\hline Hebner and Kato & 1997 & $I R E F$ \\
\hline Henderson and Fredrickson & 1996 & $A M J$ \\
\hline Henderson and Fredrickson & 2001 & $A M J$ \\
\hline Hill and Phan & 1991 & $A M J$ \\
\hline Hillman, Shropshire, Certo, Dalton, and Dalton & 2008 & WP \\
\hline Hogan and McPheters & 1980 & SEJ \\
\hline Houston and James & 1995 & $J M E$ \\
\hline Hubbard and Palia & 1995 & $J F E$ \\
\hline Iyengar and Zampelli & 2008 & $A F$ \\
\hline Jackson, Lopez, and Reitenga & 2008 & $J A P P$ \\
\hline Jalbert, Chan, Jalbert, and Landry & 2007 & $J D M$ \\
\hline Jensen and Murphy & 1990 & $J P E$ \\
\hline Jiraporn, Kim, and Davidson & 2005 & $J E S F$ \\
\hline Joyce & 2001 & $A B R$ \\
\hline Kacperczyck & 2007 & WP \\
\hline Kanagaretnam, Lobo, and Mathieu & 2004 & WP \\
\hline Kaplan & 1994 & $J P E$ \\
\hline Kato and Rockel & 1992 & $J J I E$ \\
\hline Kerr and Bettis & 1987 & $A M J$ \\
\hline Kerr and Kren & 1992 & $A M J$ \\
\hline Khan, Dharwadkar, and Brandes & 2005 & $J B R$ \\
\hline Kim & 2000 & DIS \\
\hline Kim & 2005 & DIS \\
\hline Kren and Kerr & 1997 & $A B$ \\
\hline Kruse and Rennie & 2006 & WP \\
\hline Kumar, Ghicas, and Pastena & 1993 & $M F$ \\
\hline
\end{tabular}


Appendix A (continued)

\begin{tabular}{|c|c|c|}
\hline Author & Year & Publication \\
\hline Larcker, Richardson, Seary, and Tuna & 2005 & WP \\
\hline $\begin{array}{l}\text { Larraza-Kintana, Wiseman, Gomez-Mejia, and } \\
\text { Welbourne }\end{array}$ & 2007 & $S M J$ \\
\hline Leone, Wu, and Zimmerman & 2006 & $J A E$ \\
\hline Lewellen & 2003 & WP \\
\hline Lewellen, Loderer, Martin, and Blum & 1992 & $M D E$ \\
\hline Madanoglu and Karadag & 2008 & $J F B R$ \\
\hline Magnan and Stonge & 1997 & SMJ \\
\hline Main, O'Reilly, and Wade & 1995 & $I C C$ \\
\hline Makri, Lane, and Gomez-Mejia & 2006 & $S M J$ \\
\hline Mangel and Singh & 1993 & $A B$ \\
\hline Martin and Thomas & 2005 & $J C F$ \\
\hline Matta and Beamish & 2008 & $S M J$ \\
\hline McClelland and Barker & 2007 & WP \\
\hline McDonald, Khanna, and Westphal & 2008 & $A M J$ \\
\hline McGuire, Chiu, and Elbing & 1962 & $A E R$ \\
\hline McGuire, Dow, and Argheyd & 2003 & $J B E$ \\
\hline Mehran & 1992 & $J F Q A$ \\
\hline Meyer and Elayan & 2005 & WP \\
\hline Miller & 1995 & $A M J$ \\
\hline Miller, Wiseman, and Gomez-Mejia & 2002 & $A M J$ \\
\hline Mir and Seboui & 2008 & $C G$ \\
\hline Mitsudome, Weintrop, and Hwang & 2008 & JJIE \\
\hline Moeller & 2005 & $J F E$ \\
\hline Mohan & 2004 & WP \\
\hline Murphy & 1986 & RJE \\
\hline Ning, Hu, and Garza-Gomez & 2009 & WP \\
\hline Noguera and Highfield & 2006 & WP \\
\hline Nourayi and Daroca & 2008 & $M F$ \\
\hline Nourayi and Mintz & 2008 & $M F$ \\
\hline Nwaeze, Yang, and Yin & 2006 & $C A R$ \\
\hline Offstein and Gnyawali & 2005 & JETM \\
\hline Offstein and Gnyawali & 2005 & $J M P$ \\
\hline O'Reilly, Main, and Crystal & 1988 & $A S Q$ \\
\hline Otten and Heugens & 2008 & WP \\
\hline Pathak, Hoskisson, and Johnson & 2008 & WP \\
\hline Pennathur and Shelor & 2002 & JREFE \\
\hline Pollock, Fischer, and Wade & 2002 & $A M J$ \\
\hline Porac, Wade, and Pollock & 1999 & $A S Q$ \\
\hline Rajagopalan and Finkelstein & 1992 & $S M J$ \\
\hline Reeb and Upadhyay & 2006 & WP \\
\hline Reeb and Upadhyay & 2007 & WP \\
\hline Riahi-Belkaoui and Pavlik & 1993 & $M F$ \\
\hline Riahi-Belkaoui and Picur & 1993 & $M F$ \\
\hline Rose & 2005 & CGIR \\
\hline Roulstone & 2003 & $J A R$ \\
\hline Sanders & 1999 & $M F$ \\
\hline Sanders & 2001 & $A M J$ \\
\hline Sanders and Carpenter & 1998 & $A M J$ \\
\hline Sanders and Carpenter & 2003 & $A M J$ \\
\hline Sanders and Hambrick & 2008 & $A M J$ \\
\hline Schaefer & 1998 & $R E S$ \\
\hline Schnatterly & 2003 & $S M J$ \\
\hline Seo and Carpenter & 2008 & WP \\
\hline Sheikh & 2001 & WP \\
\hline Sheikholeslami & 2001 & $A B R$ \\
\hline Shim and Lee & 2003 & $R A F$ \\
\hline Shortridge and Avila & 2004 & $R M I R$ \\
\hline Sigler & 2003 & $M R N$ \\
\hline Sigler and Haley & 1995 & $M F$ \\
\hline Sloan & 1993 & $J A E$ \\
\hline
\end{tabular}


Appendix A (continued)

\begin{tabular}{|c|c|c|}
\hline Author & Year & Publication \\
\hline Smith and Swan & 2008 & WP \\
\hline Srinivasan, Sayrak, and Nagarajan & 2004 & WP \\
\hline Stanwick and Stanwick & 2001 & $B S E$ \\
\hline Staw and Epstein & 2000 & $A S Q$ \\
\hline Sung and Swan & 2008 & WP \\
\hline Talmor and Wallace & 2001 & WP \\
\hline Tinaikar & 2006 & WP \\
\hline Tinaikar & 2008 & WP \\
\hline Tobler & 2006 & WP \\
\hline Tosi and Gomez-Mejia & 1989 & $A S Q$ \\
\hline Tosi, Misangyi, Fanelli, Waldman, and Yammarino & 2004 & $L Q$ \\
\hline Tripp and Kenny & 1995 & $A B R$ \\
\hline Vafeas & 2003 & $F M$ \\
\hline Vafeas and Afxentiou & 1998 & $J A P P$ \\
\hline Van der Laan, van Ees, and van Witteloostuijn & 2008 & WP \\
\hline Veliyath & 1999 & $J M S$ \\
\hline Veliyath and Bishop & 1995 & IJOA \\
\hline Wade, Porac, and Pollock & 1997 & $J O B$ \\
\hline Wade, Porac, Pollock, and Graffin & 2006 & $A M J$ \\
\hline Wann & 2003 & WP \\
\hline Weber & 2004 & DIS \\
\hline Westphal & 1999 & $A M J$ \\
\hline Westphal and Zajac & 1994 & $A S Q$ \\
\hline Westphal and Zajac & 1995 & $A S Q$ \\
\hline Winfrey and Logan & 1998 & $C R R$ \\
\hline Wright and Kroll & 2002 & $J M G$ \\
\hline Wright, Kroll, Lado, and van Ness & 2002 & SMJ \\
\hline $\mathrm{Wu}$ and $\mathrm{Tu}$ & 2007 & $J B R$ \\
\hline Young and Buchholtz & 2002 & $J M I$ \\
\hline Zajac and Westphal & 1994 & $S M J$ \\
\hline Zhang, Bartol, Smith, Pfarrer, and Khanin & 2008 & $A M J$ \\
\hline Zhou & 2006 & WP \\
\hline
\end{tabular}

Note: $A B=$ Accounting \& Business Research $; A B R=$ American Business Review; $A E R=$ American Economic Review AF $=$ Accounting and Finance; $A M J=$ Academy of Management Journal; $A M P=$ Academy of Management Perspective; $A R=$ Accounting Review; $A S Q=$ Administrative Science Quarterly; BS = Business Society; BSE = Business Strategy and the Environment; CAR = Contemporary Accounting Research; $C G=$ Corporate Governance CGIR $=$ Corporate Governance - An International Review $; \mathrm{CH}=$ book chapter; $C O C=$ Corporate Ownership \& Control CRR $=$ Corporate Reputation Review; DIS $=$ dissertation; EFR = European Finance Review; $F M=$ Financial Management $; G O M=$ Group \& Organization Management $;$ HR = Human Relations $;$ ICC $=$ Industrial and Corporate Change; IJOA = International Journal of Organizational Analysis; ILRR = Industrial and Labor Relations Review; IR =Industrial Relations; IREF = International Review of Economics and Finance; IRLE = International Review of Law and Economics; JAAF = Journal of Accounting, Auditing \& Finance; JAE = Journal of Accounting and Economics; JAPP = Journal of Accounting and Public Policy; JAR = Journal of Accounting Research; JB = Journal of Business; JBE = Journal of Business Ethics; JBF = Journal of Banking $\&$ Finance; $J B R=$ Journal of Business Research; JBV = Journal of Business Venturing; $J C F=$ Journal of Corporate Finance; JDM = Journal of Diversity Management; JESF = Journal of Economics and Finance; JETM = Journal of Engineering and Technology Management JF = Journal of Finance; JFBR = Journal of Foodservice Business Research; JFE = Journal of Financial Economics; JFI $=$ Journal of Financial Intermediation; JFQA = Journal of Financial and Quantitative Analysis; JFR = Journal of Financial Research; $J J I E=J o u r n a l$ of the Japanese and International Economies; JLE = Journal of Labor Economics; JLR $=$ Journal of Labor Research; JM $=$ Journal of Management $; M E=$ Journal of Monetary Economics; $J M G=$ Journal of Management and Governance; JMI = Journal of Managerial Issues; JMP = Journal of Managerial Psychology; JMS = Journal of Management Studies; JOB = Journal of Organizational Behavior; JPE = Journal of Political Economy; JREFE = Journal of Real Estate Finance and Economics; JSBM = Journal of Small Business Management; $L Q=$ Leadership Quarterly; $M D E=$ Managerial and Decision Economics; $M F=$ Managerial Finance; $M R N=$ Management Research News; QJE = Quarterly Journal of Economics; RAF = Review of Accounting and Finance; RAS $=$ Review of Accounting Studies; RES = Review of Economics and Statistics; $R F=$ Review of Finance; $R J E=R A N D$ Journal of Economics; RMIR = Risk Management and Insurance Review; RQFA = Review of Quantitative Financial and Accounting; SEJ = Southern Economic Journal; $S M J=$ Strategic Management Journal; TM = Tourism Management; $\mathrm{WP}=$ working paper. 


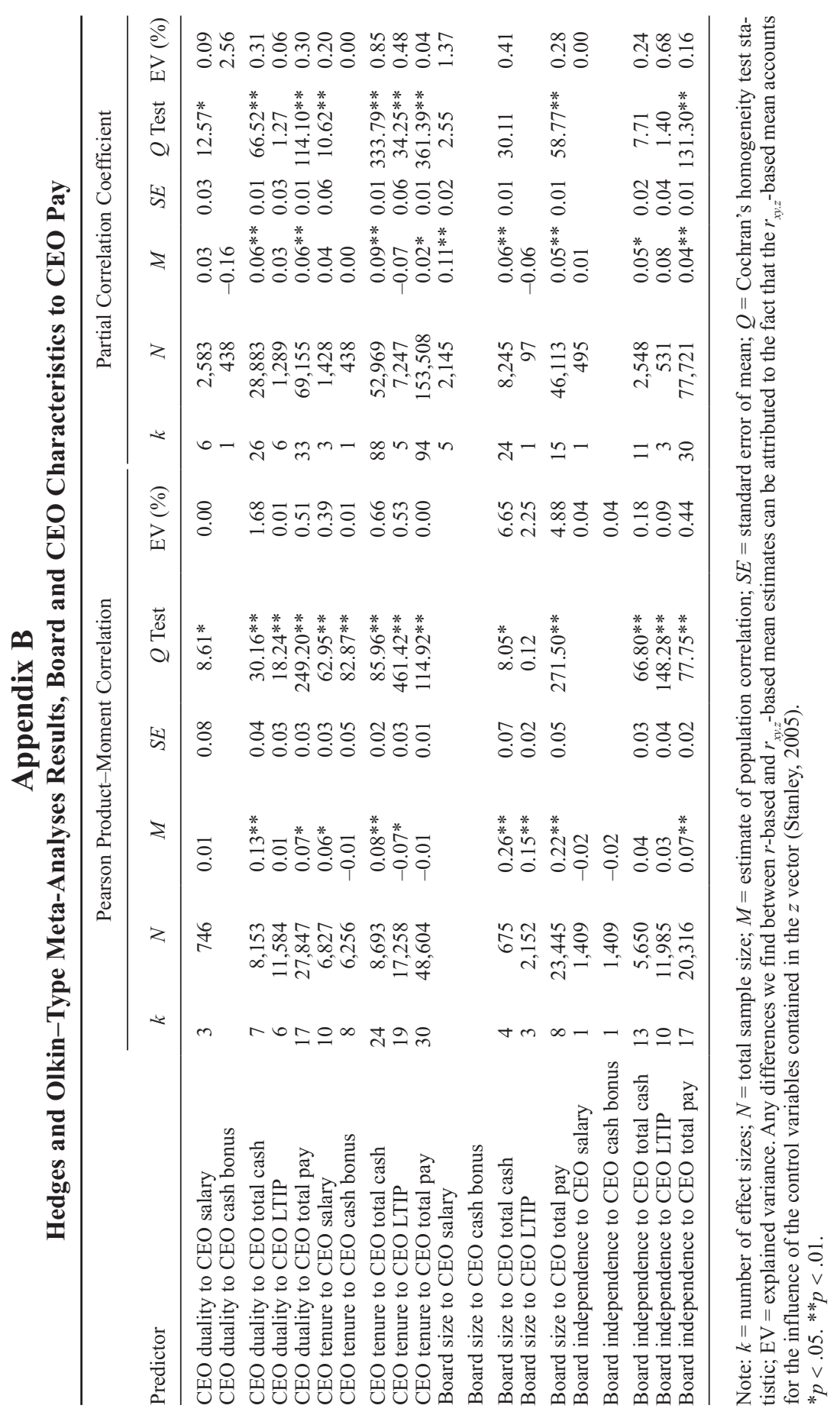




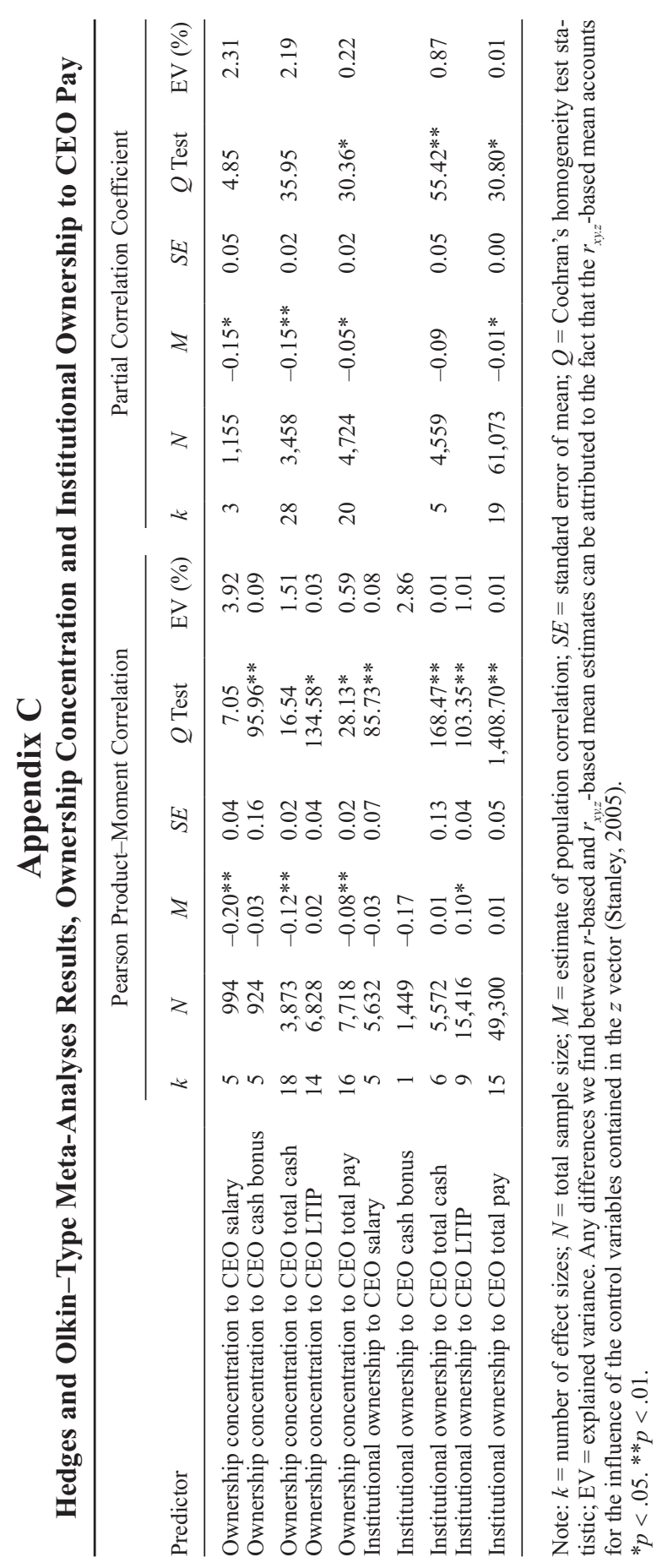




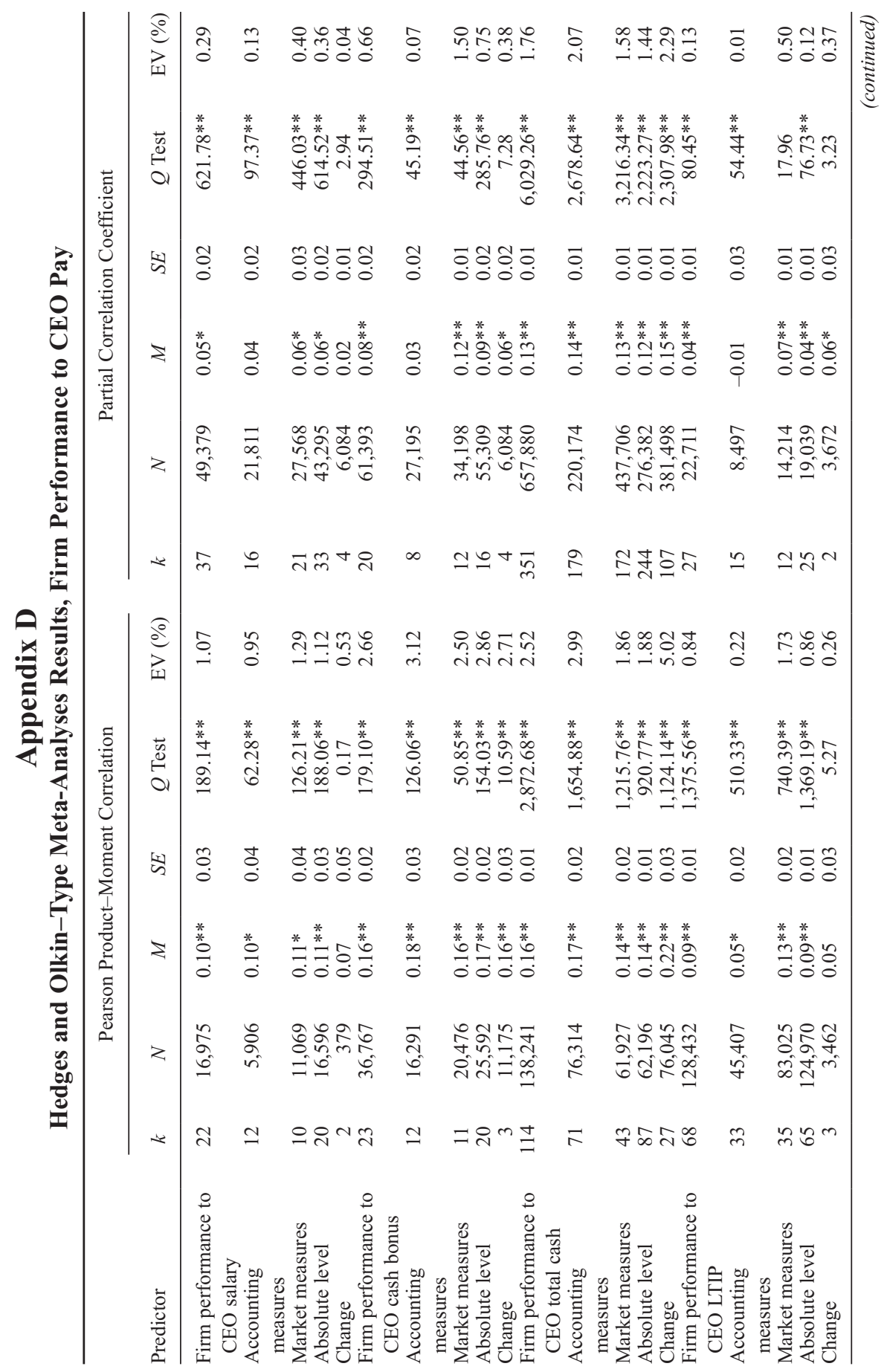




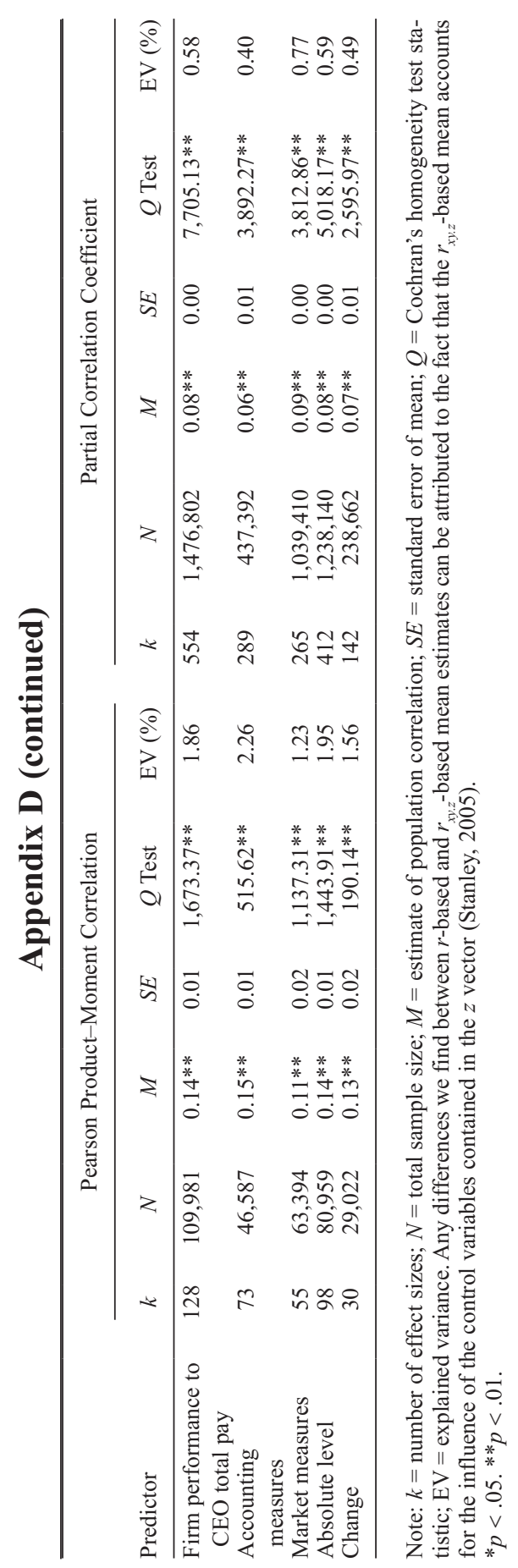




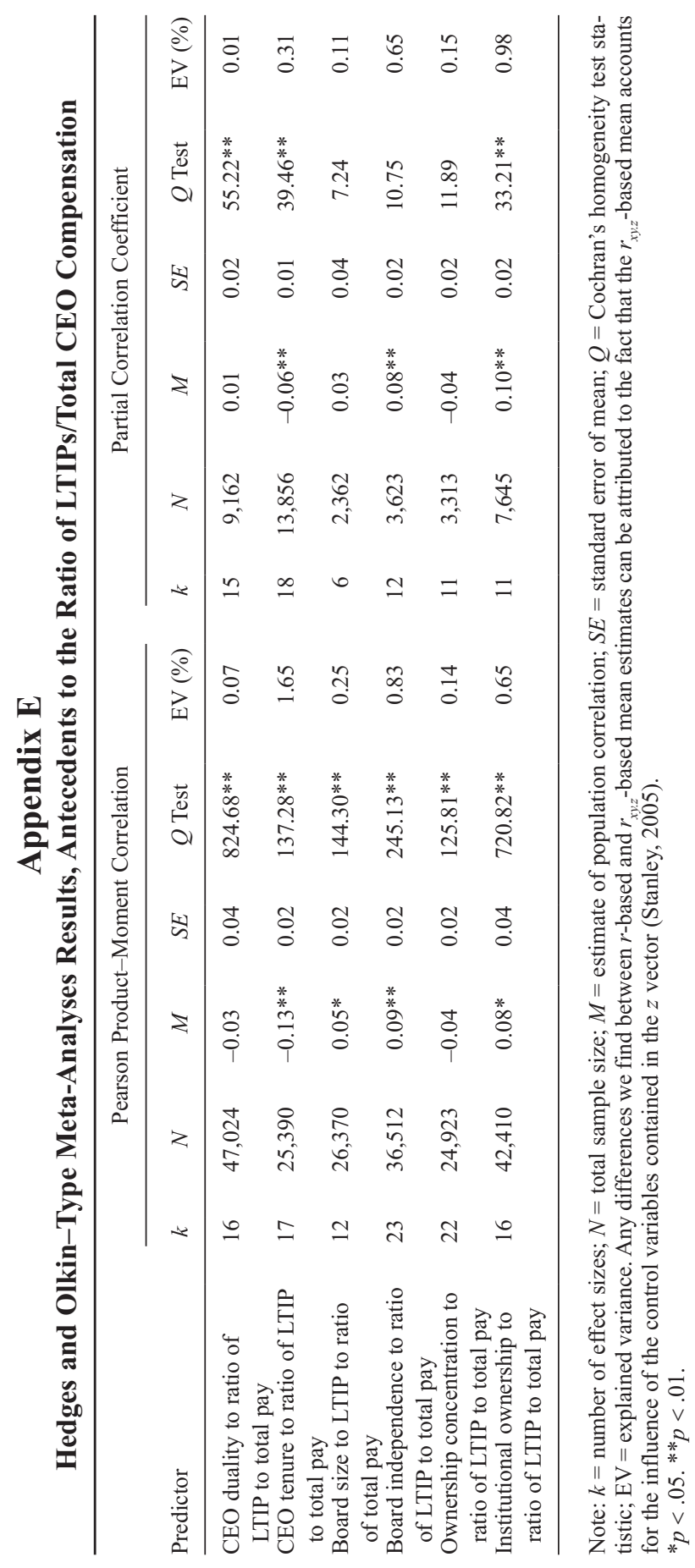




\section{Appendix F \\ Meta-Analytic Structural Equation Modeling Results, CEO Total Cash and CEO LTIP}

\begin{tabular}{|c|c|c|c|c|}
\hline \multirow[b]{2}{*}{ Predictors } & \multicolumn{2}{|c|}{ CEO Total Cash } & \multicolumn{2}{|c|}{ CEO LTIP } \\
\hline & $\beta$ & $t$ & $B$ & $t$ \\
\hline CEO duality & $.10^{* *}$ & 11.73 & $.03 * *$ & 3.29 \\
\hline CEO tenure & $.06 * *$ & 6.84 & $-.03 * *$ & -2.95 \\
\hline Board size & $.15^{* *}$ & 17.01 & $.13^{* *}$ & 12.86 \\
\hline Board independence & -.01 & -0.97 & $-.03 * *$ & -2.72 \\
\hline Ownership concentration & $-.04 * *$ & -4.75 & $.06 * *$ & 6.01 \\
\hline Institutional ownership & -.01 & -1.48 & $.07 * *$ & 7.47 \\
\hline Firm performance & $.15^{* *}$ & 17.99 & $.07 * *$ & 7.68 \\
\hline Firm size & $.27 * *$ & 31.10 & $.14 * *$ & 14.29 \\
\hline Firm debt level & $.04 * *$ & 4.33 & $-.04 * *$ & -4.02 \\
\hline Firm diversification & $.04 * *$ & 4.81 & $.05 * *$ & 5.59 \\
\hline Firm risk & $.05^{* *}$ & 5.94 & $.09 * *$ & 9.27 \\
\hline Firm R\&D level & $.12 * *$ & 13.78 & $.05 * *$ & 5.31 \\
\hline CEO age & $.05^{* *}$ & 5.40 & $-.11 * *$ & -11.11 \\
\hline Inside ownership & $-.09 * *$ & -11.03 & $-.07 * *$ & -7.58 \\
\hline Harmonic mean $N$ & 11,360 & & & \\
\hline$\chi^{2}$ & $1,433.50$ & & & \\
\hline RMSEA & .091 & & & \\
\hline RMSR & .033 & & & \\
\hline
\end{tabular}

$* * p<.01$

\section{Notes}

1. Fisher's $Z r$ transformed correlations are calculated as $z_{r}=\frac{1}{2} \operatorname{In}\left(\frac{1+r}{1-r}\right)$, where $r$ is the untransformed correlation coefficient.

2. In Hedges and Olkin-type meta-analyses (HOMA), there are two methods for combining study estimates. The first method utilizes a fixed effects model, which assumes the absence of heterogeneity between study results. In fixed effects HOMA, the collected effect sizes are solely corrected for sampling error, under the assumption that differences in sample size are the sole driver of variability between effect sizes. The second method employs random effects models and is currently favored by the meta-analytic community (Raudenbush \& Bryk, 2002). Attractively, random effects HOMA is more conservative than fixed effects HOMA when effect size distributions are heterogeneous, but both methods yield materially similar results when the distribution is homogeneous (Lipsey \& Wilson, 2001). The random effects method assumes that studies are estimating different effect sizes, which are corrected for sampling error, plus a value that represents other sources of variability, which are in turn assumed to be randomly distributed. In short, we opt for random effect HOMA.

3. $w$ is calculated as $w_{i}=\frac{1}{s e_{i}^{2}+\hat{v}_{\theta}}$, where $S E$ is the standard error of the effect size and $\hat{v}$ is the random effects variance component, which is in turn calculated as S.e. $\left(z_{r}\right)=\frac{1}{\sqrt{n-3}}$, and the formula of random effect variance is $\hat{v}_{\theta}=\frac{Q_{T}-k-1}{\Sigma w-\left(\frac{\Sigma w^{2}}{\Sigma w}\right)}$. 
4. The meta-analytic mean is calculated as $\overline{E S}=\frac{\sum(w \times E S)}{\sum w}$, with its standards error as $s e_{\overline{E S}}=\sqrt{\frac{1}{\Sigma w}}$, and with its $95 \%$ confidence interval computed as Lower $=\overline{E S}-1.96\left(s e_{\overline{E S}}\right), \quad$ Upper $=\overline{E S}-1.96\left(s e_{\overline{E S}}\right)$.

5. Partial correlations are computed as $\sqrt{ }\left(\mathrm{t}^{2} /\left(\mathrm{t}^{2}+\mathrm{df}\right)\right)$, where $t$ is the $t$-statistic and $d f$ is the degrees of freedom. Note that this will always produce a positive number, so it is necessary to convert it to a negative number if the regression coefficient is negative (see Greene, 2008: chap. 3). $t$-values result from the scaling of primary coefficients by their respective standard errors. They are by definition standardized and defined on a dimensionless scale.

6. The problem of endogeneity occurs when the independent variable is correlated with the error term in a regression model, or when the dependent variable (i.e., the executive compensation measure) simultaneously affects the independent variable (i.e., firm performance). There are several accepted methods of controlling for endogeneity. Endogeneity-conscious researchers usually use a fixed or random effects panel data model and calculate instrumental variables using two- or three-stages least squares or the generalized method of moments (SánchezBallesta \& García-Meca, 2007).

7. The $Q$ test is computed by summing the squared deviations of each study's effect estimate from the overall effect estimate. In this exercise, each study is weighted by its $w$. The $Q$ test assumes homogeneity, following a chisquare distribution with $k-1$ degrees of freedom ( $k=$ the number of studies). When $Q$ is significant, as it is in our case most of the time, the assumption of homogeneity is rejected. This implies that the overall mean correlation reported here has to be interpreted as an average rather than a common true correlation value (Hedges \& Olkin, 1985: 235), meaning that the associational strength of the focal relationship varies significantly and requires further mediation and moderator analyses. Therefore, we use more advanced meta-analytic structural equation modeling (MASEM) and meta-analytic regression analyses (MARA) techniques to test our hypotheses.

8. The robustness checks we performed consisted of different HOMA analyses on subgroups of our data that (a) consisted of primary studies that had nonoverlapping time periods, and (b) we split the total sample by particular sources of compensation data, including only the largest nonoverlapping samples. More specifically, when two or more samples included overlapping firm-year observations, we retained only the largest sample and excluded the smaller one(s). The results of these robustness checks are not reported here because of space constraints but are available on request. The HOMA results for the different pay components in relation to form size are also available on request.

9. We thank an anonymous reviewer for pointing us to this alternative explanation.

\section{References}

Aguinis, H., Gottfredson, R. K., \& Wright, T. A. in press. Best-practice recommendations for estimating interaction effects using meta-analysis. Journal of Organizational Behavior.

Attaway, M. C. 2000. A study of the relationship between company performance and CEO compensation. American Business Review, 18: 77-85.

Bahadir, S. C., Bharadwaj, S., \& Parzan, M. in press. A meta-analysis of the determinants of organic sales growth. International Journal of Research in Marketing.

Baker, G. P., Jensen, M. C., \& Murphy, K. J. 1988. Compensation and incentives: Practice vs. theory. Journal of Finance, 43: 593-616.

Balkin, D. B., Markman, G. D., \& Gomez-Mejia, L. R. 2000. Is CEO pay in high-technology firms related to innovation. Academy of Management Journal, 43: 1118-1129.

Barkema, H. G., \& Gomez-Mejia, L. R. 1998. Managerial compensation and firm performance: A general research framework. Academy of Management Journal, 41: 135-145.

Bebchuk, L. A., \& Fried, J. M. 2003. Executive compensation as an agency problem. Journal of Economic Perspectives, 17: 71-92.

Bebchuk, L. A., \& Fried, J. M. 2004. Pay without performance: The unfulfilled promise of executive compensation. Cambridge, MA: Harvard University Press.

Bebchuk, L. A., \& Fried, J. M. 2006. Pay without performance: Overview of the issues. Journal of Applied Corporate Finance, 17: 8-23. 
Bebchuk, L. A., Fried, J. M., \& Walker, D. I. 2002. Managerial power and rent extraction in the design of executive compensation. University of Chicago Law Review, 69: 751-846.

Berle, A. A., Jr., \& Means, G. C. 1932. The modern corporation and private property. New York: Macmillan.

Berrone, P., \& Gomez-Mejia, L. R. 2009. Environmental performance and executive compensation: An integrated agency-institutional perspective. Academy of Management Journal, 52: 103-126.

Blau, P. M. 1964. Exchange and power in social life. New York: John Wiley.

Boyd, B. K. 1994. Board control and CEO compensation. Strategic Management Journal, 15: 335-344.

Carney, M., Gedajlovic, E., Heugens, P. P. M. A. R., van Essen, M., \& van Oosterhout, J. 2011. Business group affiliation, performance, context, and strategy: A meta-analysis. Academy of Management Journal, 54: 437-460.

Carpenter, M. A., Sanders, G., \& Gregersen, H. B. 2001. Bundling human capital with organizational context: The impact of international assignment experience on multinational firm performance and CEO pay. Academy of Management Journal, 44: 493-511.

Cheung, M. W. L., \& Chan, W. 2005. Meta-analytic structural equation modeling: A two-stage approach. Psychological Methods, 10: 40-64.

Cohen, J. 1960. A coefficient of agreement for nominal scales. Educational and Psychological Measurement, 20: 37-46.

Combs, J. G., Ketchen, J. G. J., Crook, T. R., \& Roth, P. L. 2011. Assessing cumulative evidence within "macro" research: Why meta-analysis should be preferred over vote counting. Journal of Management Studies, 48: 178197.

Conyon, M. J. 2006. Executive compensation and incentives. Academy of Management Perspectives, 20: 25-44.

Conyon, M. J., \& He, L. 2004. Compensation committees and CEO compensation incentives in US entrepreneurial firms. Journal of Management Accounting Research, 16: 35-56.

Conyon, M. J., \& Murphy, K. J. 2000. The prince and the pauper: CEO pay in the US and UK. Economic Journal, 110: 640-671.

Conyon, M. J., \& Peck, S. I. 1998. Board control, remuneration committees, and top management compensation. Academy of Management Journal, 41: 146-157.

Core, J. E., Holthausen, R. W., \& Larcker, D. F. 1999. Corporate governance, chief executive officer compensation, and firm performance. Journal of Financial Economics, 51: 371-406.

Dalton, D. R., Daily, C. M., Certo, S. T., \& Roengpitya, R. 2003. Meta-analyses of financial performance and equity: Fusion or confusion? Academy of Management Journal, 46: 13-26.

Dalton, D. R., Daily, C. M., Ellstrand, A. E., \& Johnson, J. L. 1998. Meta-analytic reviews of board composition, leadership structure, and financial performance. Strategic Management Journal, 19: 269-290.

David, P., Kochhar, R., \& Levitas, E. 1998. The effect of institutional investors on the level and mix of CEO compensation. Academy of Management Journal, 41: 200-208.

Deutsch, Y. 2005. The impact of board composition on firms' critical decisions: A meta-analytic review. Journal of Management, 31: 424-444.

Devers, C., Cannella, A., Reilly, G., \& Yoder, M. 2007. Executive compensation: A multidisciplinary review of recent developments. Journal of Management, 33: 1016-1072.

Diprete, T. A., Eirich, G., \& Pittinsky, M. 2010. Compensation benchmarking, leapfrogs, and the surge in executive pay. American Journal of Sociology, 16: 1671-1712.

Doucouliagos, H., \& Ulubaşoğlu, M. A. 2008. Democracy and economic growth: A meta-analysis. American Journal of Political Science, 52: 61-83.

Eisenberg, T., Sundgren, S., \& Wells, M. T. 1998. Larger board size and decreasing firm value in small firms. Journal of Financial Economics, 48: 35-54.

Emerson, R. M. 1962. Power-dependence relations. American Sociological Review, 27: 31-41.

Fama, E. F., \& Jensen, M. C. 1983. Separation of ownership and control. Journal of Law and Economics, 26: 301326.

Finkelstein, S. 1992. Power in top-management teams: Dimensions, measurement and validation. Academy of Management Journal, 35: 505-538.

Finkelstein, S., \& D’Aveni, R. A. 1994. CEO duality as a double-edged-sword-How boards of directors balance entrenchment avoidance and unity of command. Academy of Management Journal, 37: 1079-1108.

Finkelstein, S., \& Hambrick, D. C. 1988. Chief executive compensation: A synthesis and reconciliation. Strategic Management Journal, 9: 543-558. 
Finkelstein, S., \& Hambrick, D. C. 1989. Chief executive compensation: A study of the intersection of markets and political processes. Strategic Management Journal, 10: 121-134.

Finkelstein, S., Hambrick, D. C., \& Cannella, B. 2009. Strategic leadership: Theory and research on executives, top management teams, and boards. Oxford, UK: Oxford University Press.

Fisher, R. A. 1928. Statistical methods for research workers (2nd ed.). London: Oliver \& Boyd.

Geyskens, I., Krishnan, R., Steenkamp, J.-B. E. M., \& Cunha, P. V. 2009. A review and evaluation of meta-analysis practices in management research. Journal of Management, 35: 393-419.

Geyskens, I., Steenkamp, J. B. E. M., \& Kumar, N. 2006. Make, buy, or ally: A transaction cost theory metaanalysis. Academy of Management Journal, 49: 519-543.

Gomez-Mejia, L., \& Wiseman, R. 1997. Reframing executive compensations: An assessment and outlook. Journal of Management, 23: 291-374.

Gray, S. R., \& Cannella, A. A. 1997. The role of risk in executive compensation. Journal of Management, $23: 517-$ 540.

Greene, W. H. 2008. Econometric analysis. Upper Saddle River, NJ: Pearson Prentice Hall.

Gregg, P., Machin, S., \& Szymanski, S. 1993. The disappearing relationship between directors' pay and corporate performance. British Journal of Industrial Relations, 31: 1-9.

Grossman, W., \& Cannella, A. A. 2006. The impact of strategic persistence on executive compensation. Journal of Management, 32: 257-278.

Hall, B. J., \& Murphy, K. J. 2003. The trouble with stock option. Journal of Economic Perspectives, 17: 49-70.

Hambrick, D. C., \& Finkelstein, S. 1995. The effects of ownership structure on conditions at the top: The case of CEO pay raises. Strategic Management Journal, 16: 175-193.

Harris, D., \& Helfat, C. 1997. Specificity of CEO human capital and compensation. Strategic Management Journal, 18: 895-920.

Hartzell, J. C., \& Starks, L. T. 2003. Institutional investors and executive compensation. Journal of Finance, 58 : 2351-2374.

Hedges, L. V., \& Olkin, I. 1985. Statistical methods for meta-analysis. Orlando, FL: Academic Press.

Heugens, P. P. M. A. R., \& Lander, M. 2009. Structure! Agency! (and other quarrels): A meta-analysis of institutional theories of organization. Academy of Management Journal, 52: 61-85.

Heugens, P. P. M. A. R., van Essen, M., \& van Oosterhout, H. 2009. Meta-analyzing ownership concentration and firm performance in Asia: Towards a more fine-grained understanding. Asia-Pacific Journal of Management, 26: 481-512.

Hill, C. W. L., \& Phan, P. 1991. CEO tenure as a determinant of CEO pay. Academy of Management Journal, 34: 707-717.

Hirschman, A. 1970. Exit, voice and loyalty: Responses to decline in firms, organizations and states. Cambridge, MA: Harvard University Press.

Jensen, M. C., \& Meckling, W. H. 1976. The theory of the firm: Managerial behavior, agency costs and ownership structure. Journal of Financial Economics, 3: 305-360.

Kaplan, S. N. 2008. Are U.S. CEOs overpaid? Academy of Management Perspectives, 22: 5-20.

Khan, R., Dharwadkar, R., \& Brandes, P. 2005. Institutional ownership and CEO compensation: A longitudinal examination. Journal of Business Research, 58: 1078-1088.

Lambert, R. A., Larcker, D. F., \& Weigelt, K. 1993. The structure of organizational incentives. Administrative Science Quarterly, 38: 438-461.

Lipsey, M. W., \& Wilson, D. B. 2001. Practical meta-analysis. Thousand Oaks, CA: Sage.

Macey, J. R. 2008. Corporate governance: Promises kept, promises broken. Princeton, NJ: Princeton University Press.

Main, B. G. M., O’Reilly, C. A., \& Wade, J. 1995. The CEO, the board of directors, and executive compensation: Economic and psychological perspectives. Industrial and Corporate Change, 4: 293-332.

McDonald, M. L., Khanna, P., \& Westphal, J. D. 2008. Getting them to think outside the circle: Corporate governance, CEOs' external advice networks, and firm performance. Academy of Management Journal, 51: 453-475.

Mehran, H. 1995. Executive compensation structure, ownership, and firm performance. Journal of Financial Economics, 38: 163-184. 
Miller, C. C., \& Cardinal, L. B. 1994. Strategic planning and firm performance: A synthesis of more than two decades of research. Academy of Management Journal, 37: 1649-1665.

Miller, J. S., Wiseman, R. M., \& Gomez-Mejia, L. R. 2002. The fit CEO compensation design and firm risk. Academy of Management Journal, 45: 745-756.

Murphy, K. J. 1999. Executive compensation. In O. Ashenfelter \& D. Card (Eds.), Handbook of labor economics: 2485-2563. Amsterdam: Elsevier.

Murphy, K. J. 2002. Explaining executive compensation: Managerial power vs. the perceived cost of stock options. University of Chicago Law Review, 69: 847-869.

Murphy, K. J., \& Zábojník, J. 2004. CEO pay and appointments: A market-based explanation for recent trends. American Economic Review, 94: 192-196.

Nourayi, M. M., \& Mintz, S. M. 2008. Tenure, firm's performance, and CEO compensation. Managerial Finance, 34: 524-536.

O’Reilly, C. A., \& Main, B. G. M. 2010. Economic and psychological perspectives on CEO compensation: A review and synthesis. Industrial and Corporate Change, 19: 675-712.

Pablo, A. L. 1997. Reconciling predictions of decision making under risk: Insights from a reconceptualized model of risk behavior. Journal of Managerial Psychology, 12: 4-20.

Pearce, J. A., \& Zahra, S. A. 1991. The relative power of CEOs and board of directors: Associations with corporate performance. Strategic Management Journal, 12: 135-153.

Pfeffer, J. 1972. Size and composition of corporate boards of directors: The organization and its environment. Administrative Science Quarterly, 17: 218-228.

Pfeffer, J., \& Salancik, G. G. 1978. The external control of organizations: A resource dependence perspective. New York: Harper \& Row.

Raudenbush, S. W., \& Bryk, A. S. 2002. Hierarchical linear models: Applications and data analysis methods (2nd ed.). Thousand Oaks, CA: Sage.

Rhoades, D. L., Rechner, P. L., \& Sundaramurthy, C. 2001. A meta-analysis of board leadership structure and financial performance: Are "two heads better than one"? Corporate Governance: An International Review, 9: 311-319.

Rosenthal, R. 1979. The "file drawer problem" and tolerance for null results. Psychological Bulletin, 86: 638-641.

Sánchez-Ballesta, J. P., \& García-Meca, E. 2007. A meta-analytic vision of the effect of ownership structure on firm performance. Corporate Governance: An International Review, 15: 879-892.

Sanders, G. 2001. Behavioral responses of CEOs to stock ownership and stock option pay. Academy of Management Journal, 44: 477-492.

Shleifer, A., \& Vishny, R. W. 1986. Large shareholders and corporate control. Journal of Political Economy, 94: 461-488.

Shleifer, A., \& Vishny, R. W. 1997. A survey of corporate governance. Journal of Finance, 52: 737-783.

Smith, M. P. 1996. Shareholder activism by institutional investors: Evidence from CalPERS. Journal of Finance, 51: $227-252$

Stanley, T. D. 2005. Beyond publication bias. Journal of Economic Surveys, 19: 309-345.

Stanley, T. D., \& Jarrell, S. B. 2005. Meta-regression analysis: A quantitative method of literature surveys. Journal of Economic Surveys, 19: 299-308.

Staw, B. M., \& Epstein, L. S. 2000. What bandwagons brings: Effects of popular management techniques on corporate performance, reputation, and CEO pay. Administrative Science Quarterly, 45: 523-556.

Thomsen, S., \& Pedersen, T. 2000. Ownership structure and economic performance in the largest European companies. Strategic Management Journal, 21: 689-705.

Tosi, H., \& Greckhamer, T. 2004. Culture and CEO compensation. Organization Science, 15: 657-670.

Tosi, H., Werner, S., Katz, J., \& Gomez-Mejia, L. 2000. How much does performance matter? A meta-analysis of CEO pay studies. Journal of Management, 26: 301-339.

Ungson, G. R., \& Steers, R. M. 1984. Motivation and politics in executive compensation. Academy of Management Review, 9: 313-323.

Useem, M. 1996. Investor capitalism: How money managers are changing the face of corporate America. New York: Basic Books.

van Essen, M., van Oosterhout, H., \& Carney, M. in press. Corporate boards and performance of Asian firms: A meta-analysis. Asia Pacific Journal of Management. 
Westphal, J. D., \& Stern, I. 2007. Flattery will get you everywhere (especially if you are a male Caucasian): How ingratiation, boardroom behavior, and demographic minority status affect additional board appointments at U.S. companies. Academy of Management Journal, 50: 267-288.

Westphal, J. D., \& Zajac, E. J. 1995. Who shall govern? CEO, board power, demographic similarity, and new director selection. Administrative Science Quarterly, 40: 60-83.

Wiseman, R. M., Cuevas-Rodriguez, G., \& Gomez-Mejia, L. R. in press. Toward a social theory of agency. Journal of Management Studies.

Yermack, D. 1996. Higher market valuation of companies with a small board of directors. Journal of Financial Economics, 40: 185-211.

Zahra, S. H., \& Pearce, J. P. 1989. Board of directors and corporate financial performance: A review and integrative model. Journal of Management, 15: 291-324.

Zajac, E. J., \& Westphal, J. D. 2004. The social construction of market value: Institutionalization and learning perspectives on stock market reactions. American Sociological Review, 69: 433-445. 